\title{
Oligoalanine Helical Callipers for Cell Penetration
}

Marta Pazo, ${ }^{a}$ Marisa Juanes, ${ }^{a}$ Irene Lostalé-Seijo ${ }^{a} \&$ Javier Montenegro ${ }^{a}$

${ }^{a}$ Centro Singular de Investigación en Química Biolóxica e Materiais Moleculares (CIQUS), Departamento de Química Orgánica, Universidade de Santiago de Compostela, 15782 Santiago de Compostela, Spain.

*e-mail: javier.montenegro@usc.es

\section{Supporting information}

\section{Table of contents:}

Materials and methods

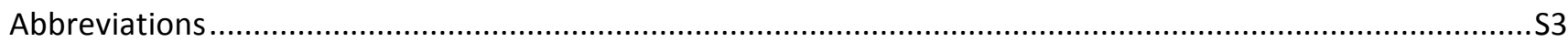

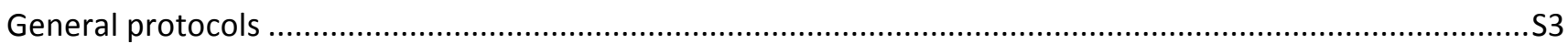

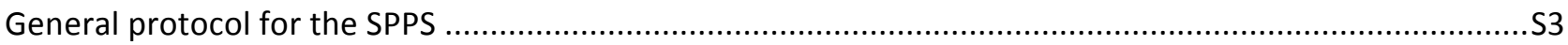

General protocol for peptide cleavage and purification ............................................................................. 4

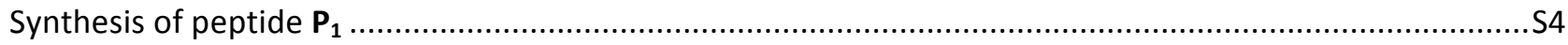

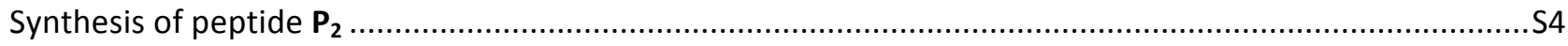

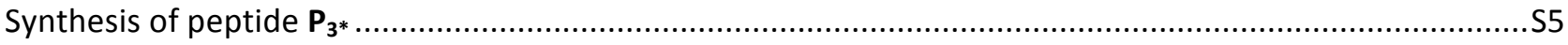

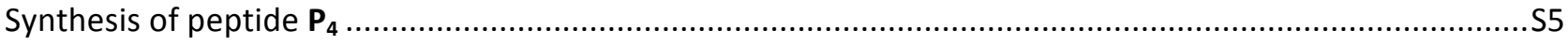

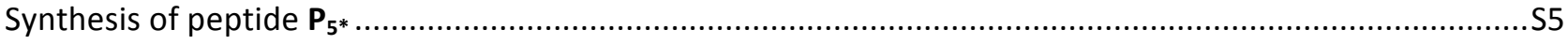

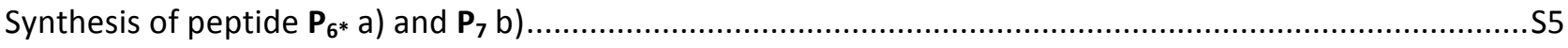

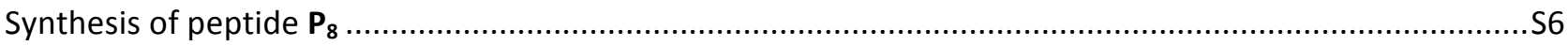

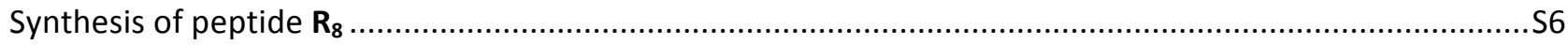

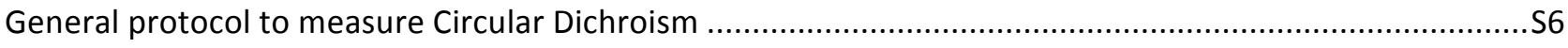

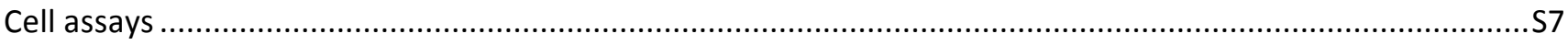

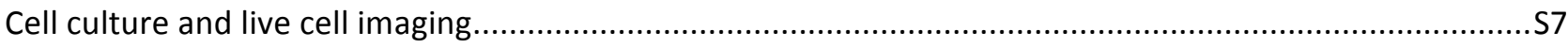

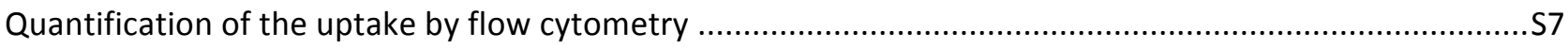

Quantification of inhibition the uptake by flow cytometry .................................................................... 8

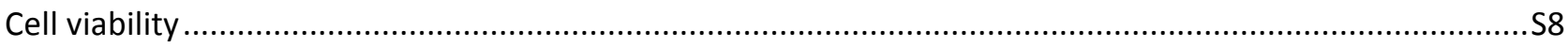

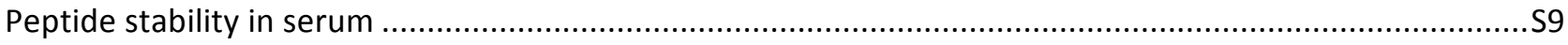

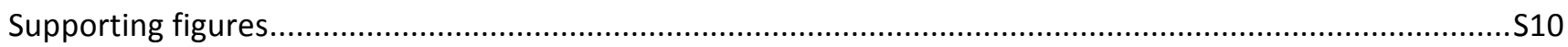

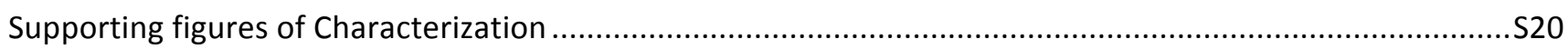

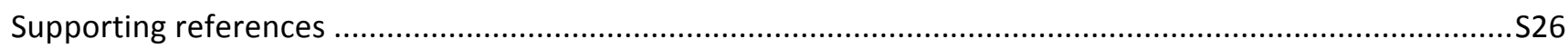




\section{Materials and methods}

Commercially available Rink Amide-resin ChemMatrix, Fmoc- $L$-Ala-OH, Fmoc- $L$-Leu-OH, Fmoc- $L$ $\operatorname{Arg}(\mathrm{pbf})-\mathrm{OH}$, triisopropylsilane (TIS), Disopropylethyl amine (DIEA), diisopropylcarbodiimide (DIC) were obtained from Sigma-Aldrich. Trifluoroethanol, 1,1,1,3,3,3-Hexafluoroisopropanol (HFIP) was purchased from TCI. Egg yolk L- $\alpha$-phosphatidylcholine was purchased from Avanti Polar Lipids. Ethyl(hydroxyimino)cyanoacetate (Oxyma) and 5-carboxytetramethyl rhodamine (TAMRA) were available from Carbosynth. $N$-HATU by Glentham life sciences. $N$-HBTU was obtained from Iris. Peptide synthesis grade $N, N$-dimethylformamide was purchased from Scharlau. Deuterated solvent $\left(\mathrm{D}_{2} \mathrm{O}\right)$ was from EMD Millipore Corporation. All the other solvents were HPLC grade, purchased from SigmaAldrich $^{\circledR}$ or Fisher Scientific ${ }^{\circledR}$, and used without further purification.

Chlorpromazine was purchased from TCI Chemicals. Ammonium chloride, Chloroquine, Heparin sodium salt and 5-(N-Ethyl-N-isopropyl)amiloride were purchased from Sigma-Aldrich. Methyl- $\beta$-cyclodextrin was purchased from Carbosynth. Hoechst 33342 Trihydrochloride Trihydrate, and LysoTracker Deep Red were purchased in ThermoFisher. Wortmannin was obtained from Fluorochem. Dulbecco's Modified Eagle's Medium (4500 mg/L glucose, L-glutamine, sodium pyruvate and sodium bicarbonate) was purchased from Gibco.

A microwave assisted peptide synthesiser (Liberty Lite, CEM) was used to prepare the peptide according to standard methods developed by the manufacturers involving diisopropylcarbodiimide (DIC) $0.5 \mathrm{M}$ in DMF as activator and ethyl(hydroxyimino)cyanoacetate (Oxyma) $1 \mathrm{M}$ in DMF as activator base. Previous to HPLC, a quick size exclusion chromatography in sephadex G-25 eluted with Milli-Q water was carried out to remove the excess of fluorophore. High-performance liquid chromatography coupled with mass spectrometry (HPLC-MS) analyses were carried out on Agilent Technologies 1260 Infinity II associated with a 6120 Quadrupole LC-MS using an Agilent SB-C18 column or on DIONEX Ultimate 3000 UHPLC $^{+}$(Thermo Scientific) with an Acclaim RSLC 120-C18 column with Solvent A:Solvent B gradients between 5:95 (Solvent $A$ : $\mathrm{H}_{2} \mathrm{O}$ with $0.1 \%$ TFA; Solvent $B: \mathrm{CH}_{3} \mathrm{CN}$ with $0.1 \%$ TFA). High-performance liquid chromatography (HPLC) semi-preparative purification was carried out on Jasco LC-4000 with an Agilent Eclipse XDB-C18 column.

Nuclear Magnetic Resonance (NMR) spectra were recorded on a Varian Mercury $300 \mathrm{MHz}$. Chemical shifts are reported in ppm referenced to the following solvent signals: HOD $\delta$ H $4.79 \mathrm{ppm}$. Spin multiplicities are reported as a singlet (s), doublet (d), triplet (t) with coupling constants $(J)$ given in Hz, or multiplet (m). Accurate mass determinations (HR-MS) using ESI-MS were performed on a Bruker MicroTof mass spectrometer.

Circular Dichroism (CD) measurements were performed with a Jasco J-1100 CD Spectrometer equipped with a Jasco MCB-100 Mini Circulation Bath for temperature control.

For the acquisition of cell microscopy images an Andor Zyla 4.2 digital camera mounted on a Nikon Eclipse Ti-E epifluorescence microscope was used, and to do the images in 3D a Dragonfly confocal spinning-disk on a Nikon Eclipse Ti-E equipped with a Andor Zyla 4.2 PLUS sCMOS digital camera. The 
3D projection was obtained from the different individual confocal planes with Imaris bitplane (c) 9.0.0 software.

A Tecan Infinite F200Pro microplate reader was used to measure directly in Costar cell culture 96-well plates UV-Vis absorbance for the MTT viability assays.

Flow cytometry was performed on a Guava easyCyteTM cytometer. Data analysis was performed with InCyte software included in GuavaSoft 3.2 (Millipore).

\section{Abbreviations}

Aa: Amino acid; Arg: Arginine; Calcd: Calculated; CLQ: Chloroquine; CPZ: Chlorpromazine; DCM: Dichloromethane; DIC: diisopropylcarbodiimide; DIEA: $N, N$-Diisopropylethylamine; DMF: $N, N$ Dimethylformamide; DYN: Dynasore; EIPA: 5-( $N$-Ethyl- $N$-isopropyl)amiloride; EYPC: Egg yolk phosphatidylcholine; Hep: Heparin sodium salt; HFIP: 1,1,1,3,3,3-Hexafluoro-2-propanol; HRMS (ESI): High resolution mass spectrometry (electrospray ionization); Leu: Leucine; Lys: Lysine; MbCD: Methylbeta-Cyclodextrin; Mtt: 4-Methyltrytil; $N$-HATU:N-[(Dimethylamino)-1H-1,2,3-triazolo[4,5-b]pyridine1 ylmethylene]- $N$-methylmethanaminium-hexafluorophosphate $N$-oxide; $N$-HBTU: $N$-[(1HBenzotriazol-1yl)-(dimethylamino)methylene]- $N$-methylmethanaminium hexafluorophosphate $N$-oxide; Pbf: 2,2,4,6,7Pentamethyldihydrobenzofuran-5-sulfonyl; SPC: spacer; SPPS: solid phase peptide synthesis; TAMRA: 5carboxytetramethyl rhodamine; TFE: Trifluoroethanol; TNBS: 2,4,6-Trinitrobenzenesulfonic acid; TIS: Triisopropylsilane; W: Wortmannin; 6Ahx: 6-aminohexanoic acid.

\section{General protocols}

\section{General protocol for the SPPS}

All peptides were synthesized by automated or manual Fmoc solid-phase peptide synthesis ${ }^{\mathrm{S} 1}$ using Rink Amide ChemMatrix resin (loading $0.5 \mathrm{mmol} / \mathrm{g}$ ). For manual synthesis, the resin $(0.5 \mathrm{mmol}$ ) was swelled in DMF (peptide synthesis grade, $2 \mathrm{~mL}$ ) for $20 \mathrm{~min}$ in a peptide synthesis vessel prior synthesis. Coupling cycle consisted of the removal of Fmoc protecting group with a solution of piperidine in DMF (20\%, 2 $\mathrm{mL}$ ) for $10 \mathrm{~min}$ and then the mixture was filtered and the resin was washed with DMF ( $3 \times 2 \mathrm{~mL}, 1 \mathrm{~min})$. The amino acid coupling was carried out by treatment with a solution of $\alpha$-amino acids (4 equiv.), $N$ HBTU (3.95 equiv.) in DMF (2 mL), which was mixed with DIEA (0.195 M solution in DMF, 1.2 equiv.) $1 \mathrm{~min}$ before the addition and the resulting mixture was shaken by bubbling Ar for 15 min. Finally, the resin was washed with DMF (3 $\times 2 \mathrm{~mL}, 1 \mathrm{~min})$. The efficiency of each amino acid coupling and deprotection was monitored employing the TNBS test. ${ }^{\mathrm{S} 2}$

For automated synthesis, a variant of the previous protocol was used instead, according to manufacturer's recommendations. $0.05 \mathrm{mmol}$ of Rink Amide resin was placed into the peptide synthesiser reaction vessel, swollen in DMF, followed by cycles of Fmoc cleavage with piperidine $20 \%$ in DMF, washings ( $3 \times 5 \mathrm{~mL})$, then amino acid (5 equiv. $2 \mathrm{M}$ amino acid solution in DMF), DIC (10 equiv.) and Oxyma (10 equiv.) were 
added into the reaction vessel and microwaved for $5 \mathrm{~min}$ under temperature control followed by washings $(3 \times 5 \mathrm{~mL})$. All steps were performed under nitrogen atmosphere. After the linear peptide was finished the resin was transferred to a different reaction vessel to perform the peptide modification manually.

A) Linker coupling: after Fmoc cleavage with piperidine/DMF $(20 \%, 2 \mathrm{~mL})$, the linear peptide was treated with a solution of N-Fmoc-6-aminohexanoic acid (4 equiv.), $\mathrm{N}$-HBTU (3.95 equiv.) and DIEA (0.195 M solution in DMF, 1.2 equiv.) in DMF.

B) Fluorophore coupling: the Fmoc-protecting group of the lineal final peptide (or the previously attached linker) was removed by using a solution of piperidine in DMF $(20 \%, 4 \mathrm{~mL})$ for $15 \mathrm{~min}$ and the resin was washed with DMF $(3 \times 3 \mathrm{~mL})$. The coupling was carried out by the addition of a solution of 5-Carboxytetramethylrhodamine (1 equiv.), HATU (1 equiv.), and DIEA (0.195 M, 1 equiv.) in DMF ( $2 \mathrm{~mL}$ ) and the mixture was stirred by bubbling Ar for 4 hours. Finally, the resin was washed with DMF (3 x $3 \mathrm{~mL})$ and DCM $(3 \times 3 \mathrm{~mL})$.

\section{General protocol for peptide cleavage and purification}

Finally, peptides were deprotected and cleaved from the resin by standard TFA cleavage procedure at $\mathrm{rt}$ by using the TFA/DCM/ $\mathrm{H}_{2} \mathrm{O} / \mathrm{TIS}$ (90:5:2.5:2.5, $3 \mathrm{~mL}$ per $70 \mathrm{mg}$ of resin) for $2 \mathrm{~h}$. Then, the mixture was filtered, washed with TFA $(1 \mathrm{~mL})$ and the peptide was precipitated with ice-cold $\mathrm{Et}_{2} \mathrm{O}(50 \mathrm{~mL})$. The precipitate was centrifuged and dissolved in $\mathrm{H}_{2} \mathrm{O}(5 \mathrm{~mL})$.

Peptides were purified first with sephadex size exclusion chromatography (G-25, Milli-Q water) and then by semi-preparative high-performance liquid chromatography (HPLC) as previously described. Finally, the corresponding fractions were lyophilised to afford the pure peptide as pink solids.

\section{Synthesis of peptide $P_{1}$}

Following the general protocol of the SPPS followed by fluorophore coupling, $\mathbf{P}_{\mathbf{1}}$ was obtained after RPHPLC purification [Phenomenex Luna C18(2) 100A column, $\mathrm{H}_{2} \mathrm{O}\left(0.1 \%\right.$ TFA)/ $\mathrm{CH}_{3} \mathrm{CN}(0.1 \% \mathrm{TFA})$ 95:5 $\rightarrow 5: 95(0 \rightarrow 5 \mathrm{~min}), 95: 5 \rightarrow 5: 95(5 \rightarrow 35 \mathrm{~min})$ ] with an overall yield of 12\%. $R_{\mathrm{t}} 13.0$ min [RP-HPLC Agilent SB-C18 column, $\mathrm{H}_{2} \mathrm{O}(0.1 \% \mathrm{TFA}) / \mathrm{CH}_{3} \mathrm{CN}(0.1 \%$ TFA) 95:5 $\rightarrow 5: 95$ (0 $\left.\rightarrow 20 \mathrm{~min})\right]$ (Fig. S12). MS (ESI, $\left.\mathrm{H}_{2} \mathrm{O}\right): 911.9\left(35,[\mathrm{M}+2 \mathrm{H}]^{2+}\right), 608.3\left(100,[\mathrm{M}+3 \mathrm{H}]^{3+}\right), 456.5\left(35,[\mathrm{M}+4 \mathrm{H}]^{4+}\right)$. HRMS (ESI): Calcd for $\mathrm{C}_{82} \mathrm{H}_{126} \mathrm{~N}_{28} \mathrm{O}_{20}[\mathrm{M}+2 \mathrm{H}]^{2+}$ : 911.4846 ; found: 911.4839 .

\section{Synthesis of peptide $P_{2}$}

Following the general protocol of the SPPS followed by fluorophore coupling, $\mathbf{P}_{\mathbf{2}}$ was obtained after RPHPLC purification [Phenomenex Luna C18(2) 100A column, $\mathrm{H}_{2} \mathrm{O}\left(0.1 \%\right.$ TFA)/ $\mathrm{CH}_{3} \mathrm{CN}(0.1 \%$ TFA) 95:5 $\rightarrow 5: 95(0 \rightarrow 5 \mathrm{~min}), 95: 5 \rightarrow 5: 95(5 \rightarrow 35 \mathrm{~min})]$ with an overall yield of 10.7\%. $R_{\mathrm{t}} 14.6 \mathrm{~min}$ [RP-HPLC Agilent SB-C18 column, $\mathrm{H}_{2} \mathrm{O}\left(0.1 \%\right.$ TFA)/ $\mathrm{CH}_{3} \mathrm{CN}(0.1 \%$ TFA) 95:5 $\rightarrow 5: 95$ (0 $\rightarrow 20$ min)] (Fig. S13). MS (ESI, $\left.\mathrm{H}_{2} \mathrm{O}\right): 953.9\left(40,[\mathrm{M}+2 \mathrm{H}]^{2+}\right), 636.3\left(100,[\mathrm{M}+3 \mathrm{H}]^{3+}\right), 477.6\left(35,[\mathrm{M}+4 \mathrm{H}]^{4+}\right)$. HRMS (ESI): Calcd for $\mathrm{C}_{88} \mathrm{H}_{138} \mathrm{~N}_{28} \mathrm{O}_{20}[\mathrm{M}+2 \mathrm{H}]^{2+}: 953.5317$; found: 953.5316 . 
Following the general protocol of the SPPS followed by linker and fluorophore coupling, $\mathbf{P}_{3^{*}}$ was obtained after RP-HPLC purification [Phenomenex Luna C18(2) 100A column, $\mathrm{H}_{2} \mathrm{O}(0.1 \% \mathrm{TFA}) / \mathrm{CH}_{3} \mathrm{CN}(0.1 \%$ TFA) 95:5 $\rightarrow 5: 95(0 \rightarrow 5 \mathrm{~min}), 95: 5 \rightarrow 5: 95(5 \rightarrow 35 \mathrm{~min})$ ] with an overall yield of $8.7 \%$. $R_{\mathrm{t}} 14.2 \mathrm{~min}$. [RPHPLC Agilent SB-C18 column, $\mathrm{H}_{2} \mathrm{O}\left(0.1 \%\right.$ TFA)/ $\mathrm{CH}_{3} \mathrm{CN}(0.1 \%$ TFA) 95:5 $\rightarrow 5: 95$ (0 $\rightarrow 20$ min)] (Fig. S14). MS (ESI, $\left.\mathrm{H}_{2} \mathrm{O}\right): 1088.8\left(5,[\mathrm{M}+2 \mathrm{H}+\mathrm{TFA}]^{2+}\right), 1031.4\left(35,[\mathrm{M}+2 \mathrm{H}]^{2+}\right), 688.0\left(100,[\mathrm{M}+3 \mathrm{H}]^{3+}\right), 516.3$ $\left(40,[\mathrm{M}+4 \mathrm{H}]^{4+}\right)$. HRMS (ESI): Calcd for $\mathrm{C}_{97} \mathrm{H}_{155} \mathrm{~N}_{29} \mathrm{O}_{21}[\mathrm{M}+2 \mathrm{H}]^{2+}$ : 1031.0976; found: 1031.0971.

\section{Synthesis of peptide $P_{4}$}

Following the general protocol of the SPPS followed by fluorophore coupling, $\mathbf{P}_{\mathbf{4}}$ was obtained after RPHPLC purification [Phenomenex Luna C18(2) 100A column, $\mathrm{H}_{2} \mathrm{O}(0.1 \% \mathrm{TFA}) / \mathrm{CH}_{3} \mathrm{CN}(0.1 \% \mathrm{TFA})$ 95:5 $\rightarrow 5: 95(0 \rightarrow 5 \mathrm{~min}), 95: 5 \rightarrow 5: 95(5 \rightarrow 35 \mathrm{~min})]$ with an overall yield of $6.5 \%$. $R_{\mathrm{t}} 14.9 \mathrm{~min}$ [RP-HPLC Agilent SB-C18 column, $\mathrm{H}_{2} \mathrm{O}(0.1 \% \mathrm{TFA}) / \mathrm{CH}_{3} \mathrm{CN}(0.1 \%$ TFA) 95:5 $\rightarrow 5: 95$ (0 $\left.\rightarrow 20 \mathrm{~min})\right]$ (Fig. S15). MS (ESI, $\left.\mathrm{H}_{2} \mathrm{O}\right): 975.0\left(70,[\mathrm{M}+2 \mathrm{H}]^{2+}\right), 650.3\left(100,[\mathrm{M}+3 \mathrm{H}]^{3+}\right), 488.0\left(15,[\mathrm{M}+4 \mathrm{H}]^{4+}\right)$. HRMS (ESI): Calcd for $\mathrm{C}_{91} \mathrm{H}_{144} \mathrm{~N}_{28} \mathrm{O}_{20}[\mathrm{M}+2 \mathrm{H}]^{2+}$ : 974.5551 ; found: 974.5550 .

\section{Synthesis of peptide $P_{5^{*}}$}

Following the general protocol of the SPPS followed by linker and fluorophore coupling, $\mathbf{P}_{5^{*}}$ was obtained after RP-HPLC purification [Phenomenex Luna C18(2) $100 \mathrm{~A}$ column, $\mathrm{H}_{2} \mathrm{O}\left(0.1 \%\right.$ TFA)/ $\mathrm{CH}_{3} \mathrm{CN}(0.1 \%$ TFA) 95:5 $\rightarrow 5: 95(0 \rightarrow 5 \mathrm{~min}), 95: 5 \rightarrow 5: 95(5 \rightarrow 35 \mathrm{~min})]$ with an overall yield of $2.9 \%$. $R_{\mathrm{t}} 15.2 \mathrm{~min}$ [RPHPLC Agilent SB-C18 column, $\mathrm{H}_{2} \mathrm{O}(0.1 \% \mathrm{TFA}) / \mathrm{CH}_{3} \mathrm{CN}(0.1 \%$ TFA) 95:5 $\rightarrow 5: 95(0 \rightarrow 20 \mathrm{~min})]$ (Fig. S16). MS (ESI, $\left.\mathrm{H}_{2} \mathrm{O}\right): 1031.4\left(38,[\mathrm{M}+2 \mathrm{H}]^{2+}\right), 688.0\left(100,[\mathrm{M}+3 \mathrm{H}]^{3+}\right), 516.3\left(55,[\mathrm{M}+4 \mathrm{H}]^{4+}\right)$. HRMS (ESI): Calcd for $\mathrm{C}_{97} \mathrm{H}_{155} \mathrm{~N}_{29} \mathrm{O}_{21}[\mathrm{M}+2 \mathrm{H}]^{2+}$ : 1031.0976; found: 1031.0886 .

\section{Synthesis of peptide $P_{6^{*}}$ a) and $\left.P_{7} b\right)$}

a) Following the general protocol of the SPPS followed by linker and fluorophore coupling, $\mathbf{P}_{6^{*}}$ was obtained after RP-HPLC purification [Phenomenex Luna C18(2) 100A column, $\mathrm{H}_{2} \mathrm{O}\left(0.1 \%\right.$ TFA)/ $\mathrm{CH}_{3} \mathrm{CN}$ $(0.1 \%$ TFA) $95: 5 \rightarrow 5: 95(0 \rightarrow 5 \mathrm{~min}), 95: 5 \rightarrow 5: 95(5 \rightarrow 35 \mathrm{~min})]$ with an overall yield of $6.4 \% . R_{\mathrm{t}} 15.2 \min$ [RP-HPLC Agilent SB-C18 column, $\mathrm{H}_{2} \mathrm{O}\left(0.1 \%\right.$ TFA)/ $\mathrm{CH}_{3} \mathrm{CN}(0.1 \%$ TFA) 95:5 $\rightarrow 5: 95$ (0 $\rightarrow 20 \mathrm{~min})$ ] (Fig. S17). MS (ESI, $\left.\mathrm{H}_{2} \mathrm{O}\right): 1031.4\left(40,[\mathrm{M}+2 \mathrm{H}]^{2+}\right), 688.0\left(100,[\mathrm{M}+3 \mathrm{H}]^{3+}\right), 516.3\left(50,[\mathrm{M}+4 \mathrm{H}]^{4+}\right)$. HRMS (ESI): Calcd for $\mathrm{C}_{97} \mathrm{H}_{155} \mathrm{~N}_{29} \mathrm{O}_{2}[\mathrm{M}+2 \mathrm{H}]^{2+}$ : 1031.0976; found: 1031.097 .

b) Following the general protocol of the SPPS followed by fluorophore coupling, $\mathbf{P}_{7}$ was obtained after RP-HPLC purification [Phenomenex Luna C18(2) 100A column, $\mathrm{H}_{2} \mathrm{O}(0.1 \% \mathrm{TFA}) / \mathrm{CH}_{3} \mathrm{CN}(0.1 \% \mathrm{TFA})$ 95:5 $\rightarrow 5: 95(0 \rightarrow 5 \mathrm{~min}), 95: 5 \rightarrow 5: 95(5 \rightarrow 35 \mathrm{~min})]$ with an overall yield of 5.3\%. $R_{\mathrm{t}} 15.5 \mathrm{~min}$ [RP-HPLC Agilent SB-C18 column, $\mathrm{H}_{2} \mathrm{O}\left(0.1 \%\right.$ TFA)/ $\mathrm{CH}_{3} \mathrm{CN}(0.1 \%$ TFA) 95:5 $\rightarrow 5: 95$ (0 $\left.\rightarrow 20 \mathrm{~min})\right]$ (Fig. S18). MS (ESI, $\left.\mathrm{H}_{2} \mathrm{O}\right): 974.8\left(50,[\mathrm{M}+2 \mathrm{H}]^{2+}\right), 650.3\left(100,[\mathrm{M}+3 \mathrm{H}]^{3+}\right), 488.1\left(30,[\mathrm{M}+4 \mathrm{H}]^{4+}\right)$. HRMS (ESI): Calcd for $\mathrm{C}_{91} \mathrm{H}_{144} \mathrm{~N}_{28} \mathrm{O}_{20}[\mathrm{M}+2 \mathrm{H}]^{2+}$ : 974.5544; found: 974.5550 . 


\section{Synthesis of peptide $P_{8}$}

Following the general protocol of the SPPS followed by fluorophore coupling, $\mathbf{P}_{\mathbf{8}}$ was obtained after RPHPLC purification [Phenomenex Luna C18(2) $100 \mathrm{~A}$ column, $\mathrm{H}_{2} \mathrm{O}(0.1 \% \mathrm{TFA}) / \mathrm{CH}_{3} \mathrm{CN}(0.1 \% \mathrm{TFA})$ 95:5 $\rightarrow 5: 95(0 \rightarrow 5 \mathrm{~min}), 95: 5 \rightarrow 5: 95(5 \rightarrow 35 \mathrm{~min})$ ] with an overall yield of 1.7\%. $R_{\mathrm{t}} 15.2 \mathrm{~min}$ [RP-HPLC Agilent SB-C18 column, $\mathrm{H}_{2} \mathrm{O}\left(0.1 \%\right.$ TFA)/ $\mathrm{CH}_{3} \mathrm{CN}(0.1 \%$ TFA) 95:5 $\rightarrow 5: 95$ (0 $\left.\rightarrow 20 \mathrm{~min})\right]$ (Fig. S19). MS (ESI, $\left.\mathrm{H}_{2} \mathrm{O}\right): 974.8\left(40,[\mathrm{M}+2 \mathrm{H}]^{2+}\right), 650.3\left(100,[\mathrm{M}+3 \mathrm{H}]^{3+}\right), 488.1\left(23,[\mathrm{M}+4 \mathrm{H}]^{4+}\right) .{ }^{1} \mathbf{H}$ NMR $(300 \mathrm{MHz}$, $\left.\mathrm{D}_{2} \mathrm{O}\right) \delta$ 8.53-8.45 (m, 1H), 8.18-8.10 (m, 1H), 7.57-7.47 (m, 1H), 7.21-7.10 (m, 2H), 6.96-6.86 (m, 2H), $6.68(\mathrm{~s}, 2 \mathrm{H}), 4.38-4.15(\mathrm{~m}, 16 \mathrm{H}), 3.30-3.10(\mathrm{~m}, 18 \mathrm{H}), 1.94-1.59(\mathrm{~m}, 22 \mathrm{H}), 1.55-1.35(\mathrm{~m}, 30 \mathrm{H}), 1.05-0.84$ (m, 18H). HRMS (ESI): Calcd for $\mathrm{C}_{91} \mathrm{H}_{144} \mathrm{~N}_{28} \mathrm{O}_{20}[\mathrm{M}+2 \mathrm{H}]^{2+}$ : 974.5555 ; found: 974.5550 .

\section{Synthesis of peptide $\mathbf{R}_{8}$}

Following the general protocol of the SPPS followed by fluorophore coupling, R8 was obtained after RPHPLC purification [Phenomenex Luna C18(2) $100 \mathrm{~A}$ column, $\mathrm{H}_{2} \mathrm{O}(0.1 \% \mathrm{TFA}) / \mathrm{CH}_{3} \mathrm{CN}(0.1 \%$ TFA) $100: 0 \rightarrow 100: 0(0 \rightarrow 5 \mathrm{~min}), 50: 50 \rightarrow 50: 50(5 \rightarrow 35 \mathrm{~min})]$ with an overall yield of $1.7 \% . R_{\mathrm{t}} 11.4 \mathrm{~min}$ (Fig. S20) [RP-HPLC Agilent SB-C18 column, $\mathrm{H}_{2} \mathrm{O}\left(0.1 \%\right.$ TFA)/ $\mathrm{CH}_{3} \mathrm{CN}(0.1 \%$ TFA) 95:5 $\rightarrow 5: 95$ (0 $\rightarrow 20 \mathrm{~min})$. MS (ESI, $\left.\mathrm{H}_{2} \mathrm{O}\right): \quad 1067.7 \quad\left(19, \quad[\mathrm{M}+2 \mathrm{H}+3 \mathrm{TFA}]^{2+}\right), \quad 1010.8 \quad\left(10, \quad[\mathrm{M}+2 \mathrm{H}+2 \mathrm{TFA}]^{2+}\right), \quad 712.2 \quad(45$, $\left.[\mathrm{M}+3 \mathrm{H}+3 \mathrm{TFA}]^{3+}\right), 674.2\left(100,[\mathrm{M}+3 \mathrm{H}+2 \mathrm{TFA}]^{3+}\right), 636.5\left(75,[\mathrm{M}+3 \mathrm{H}+\mathrm{TFA}]^{3+}\right), 598.2\left(20,[\mathrm{M}+3 \mathrm{H}]^{3+}\right)$, $477.5\left(40,[\mathrm{M}+4 \mathrm{H}+\mathrm{TFA}]^{4+}\right), 448.9\left(30,[\mathrm{M}+4 \mathrm{H}]^{4+}\right), 359.4\left(27,[\mathrm{M}+5 \mathrm{H}]^{5+}\right)$. HRMS (ESI): Calcd for $\mathrm{C}_{79} \mathrm{H}_{131} \mathrm{~N}_{36} \mathrm{O}_{13}[\mathrm{M}+\mathrm{H}]^{+}:$1792.0679; found: 1792.0691 .

\section{General protocol to measure Circular Dichroism}

Circular dichroism measurements were carried out with the following settings: acquisition range: 300-190 nm; band width: $1.0 \mathrm{~nm}$; accumulation: 3 scans; data pitch: $1 \mathrm{~nm}$; CD scale $200 \mathrm{mdeg} / 1.0 \mathrm{dOD}$; D.I.T. (Data Integration Time): $1 \mathrm{~s}$; scanning mode: continuous; scanning speed: $200 \mathrm{~nm} / \mathrm{min}$. Measurements were done from $10{ }^{\circ} \mathrm{C}$ to $60{ }^{\circ} \mathrm{C}$ (data interval: $10{ }^{\circ} \mathrm{C}$; temp. gradient $5{ }^{\circ} \mathrm{C} / \mathrm{min}$ ) in a quartz cell of $0.2 \mathrm{~cm}$ path length at a final volume of $0.5 \mathrm{~mL}\left(\mathrm{H}_{2} \mathrm{O}\right.$ or TFE) with a final peptide concentration of $100 \mu \mathrm{M}$. The results are expressed as the mean residue molar ellipticity $[\theta]_{\text {MRt }}$ with units of degrees $\cdot \mathrm{cm}^{2} \cdot \mathrm{dmol}^{-1}$ and calculated using the equation S1. The percentage of helicity was calculated using the equation S2. For the measurements in liposomes, samples were prepared by drying under reduced pressure L- $\alpha$ phosphatidylcholine $\left(16.7 \mu \mathrm{L}, 25 \mathrm{mg} / \mathrm{mL}\right.$ solution in $\left.\mathrm{CHCl}_{3}\right)$ and peptide $(300 \mu \mathrm{L}, 100 \mu \mathrm{M})$ in $\mathrm{TFE}$ to obtain a ratio lipid/peptide of $18: 1$ in a $10 \mathrm{~mL}$ round bottomed flask. The mixture was concentrated in a rotary evaporator to dryness, forming a film. The lipid/peptide mixture were suspended in HKR buffer $(300 \mu \mathrm{L})$ to a final peptide concentration $100 \mu \mathrm{M}$ and sonicated for $45 \mathrm{~min}$ until a clear solution was obtained. Spectra were recorded in a $0.2 \mathrm{~cm}$ path length quartz cell. ${ }^{\mathrm{S} 3}$

$$
[\Theta]_{\mathrm{MRt}}=\frac{0.1 \times \theta}{\mathrm{C} \cdot \mathrm{l} \cdot \text { number of residues }}\left(\mathrm{deg} \cdot \mathrm{cm}^{2} \cdot \mathrm{dmol}^{-1}\right)
$$

Equation S1: Formula to calculate the ellipticity. $\Theta$ is the ellipticity (mdeg), $\mathrm{C}$ is the peptide concentration (M) and 1 is the cell path length $(\mathrm{cm})$. 


$$
[\Theta] \%=\frac{\Theta \mathrm{MRt}_{222}-2340}{30300} \times 100
$$

Equation S2: Formula to calculate the percent of helicity in where the molar ellipticity at $222 \mathrm{~nm}$ is an absolute value.

\section{Cell assays}

\section{Cell culture and live cell imaging}

HeLa cells were grown at $37{ }^{\circ} \mathrm{C}, 5 \% \mathrm{CO}_{2}$, in Dulbecco's Modified Eagle's Medium (4500 mg/L glucose, L-glutamine, sodium pyruvate and sodium bicarbonate; SigmaAldrich), supplemented with $10 \%$ fetal bovine serum (Sigma-Aldrich) and 1\% of Penicillin-Streptomycin-Glutamine Mix.

SF9 Cells were grown at $28{ }^{\circ} \mathrm{C}$, in mechanical stirring, in Gibco Sf-900-II medium, complemented with $10 \%$ fetal bovine serum (Sigma-Aldrich) and 1\% of Penicillin-Streptomycin-Glutamine Mix.

A-549 cells were grown at $37{ }^{\circ} \mathrm{C}, 5 \% \mathrm{CO}_{2}$, in Dulbecco's Modified Eagle's Medium (4500 mg/L glucose, L-glutamine, sodium pyruvate and sodium bicarbonate; SigmaAldrich), supplemented with $10 \%$ fetal bovine serum (Sigma-Aldrich) and 1\% of Penicillin-Streptomycin-Glutamine Mix.

For live cell imaging, HeLa cells grown on glass bottom dishes were washed with HEPES-Krebs-Ringer (HKR) buffer (5 mM HEPES, $137 \mathrm{mM} \mathrm{NaCl}, 2.68 \mathrm{mM} \mathrm{KCl}, 2.05 \mathrm{mM} \mathrm{MgCl}_{2}, 1.8 \mathrm{mM} \mathrm{CaCl}_{2}, \mathrm{pH}$ 7,4) and incubated for 30 min with $1 \mu \mathrm{M}$ Hoechst 33342 (ThermoFisher) in HKR to stain the nucleus. This solution was removed and cells were incubated for another 30 min with $0.5 ; 1 ; 3 ; 5 \mu \mathrm{M}$ of each peptide diluted in HKR buffer, washed twice with HKR and examined on an epifluorescence microscope (Nikon Eclipse TiE).

For live cell imaging, SF9 cell grown on glass bottom dishes were washed with Sf-900-II medium incubated for $30 \mathrm{~min}$ with $1 \mu \mathrm{M}$ Hoechst 33342 (ThermoFisher) in Sf-900-II to stain the nucleus. This solution was removed and cells were incubated for another 30 min with $1 ; 3 ; 5 ; 7 \mu \mathrm{M}$ of each (Peptides) diluted in Sf-900-II medium, washed twice with Sf-900-II and examined on an epifluorescence microscope (Nikon Eclipse Ti-E).

For live cell imaging, A-549 cells grown on glass bottom dishes were washed with HEPES-Krebs-Ringer (HKR) buffer (5 mM HEPES, $137 \mathrm{mM} \mathrm{NaCl}, 2.68 \mathrm{mM} \mathrm{KCl}, 2.05 \mathrm{mM} \mathrm{MgCl}_{2}, 1.8 \mathrm{mM} \mathrm{CaCl}_{2}, \mathrm{pH} 7.4$ ) and incubated for 30 min with $1 \mu \mathrm{M}$ Hoechst 33342 (ThermoFisher) in HKR to stain the nucleus. This solution was removed and cells were incubated for another 30 min with $0.5 ; 1 ; 3 ; 5 \mu \mathrm{M}$ of each peptide diluted in HKR buffer, washed twice with HKR and examined on an epifluorescence microscope (Nikon Eclipse TiE).

\section{Quantification of the uptake by flow cytometry}

For internalization standard assays, we measured the amount of peptide by flow cytometry. Briefly, semiconfluent monolayers of HeLa cells seeded the day before were washed twice with HKR before incubation with different concentrations $(1,3,5,7,10 \mu \mathrm{M})$ of TAMRA labelled peptides for 1 hour at 37 
${ }^{\circ} \mathrm{C}$. Then, cells were trypsinized to remove membrane bound peptides ${ }^{\mathrm{S}, \mathrm{S} 5}$ and to prepare the samples for flow cytometry using $100 \mu \mathrm{L}$ of Trypsin-EDTA (Gibco) for $10 \mathrm{~min}$ at $37^{\circ} \mathrm{C}$, and trypsin neutralized with $100 \mu \mathrm{L}$ of $2 \%$ FBS in PBS with 5 mM EDTA. Pipetting broke cell clumps and the analysis was done in a Guava easyCyte $^{\mathrm{TM}}$ cytometer. TAMRA levels were determined by excitation at $532 \mathrm{~nm}$ and detection at $575 / 25 \mathrm{~nm}$. For the analysis, cells with typical FSC and SSC parameters were selected, and median fluorescence intensity was calculated for each sample. Data analysis was performed with InCyte software included in GuavaSoft 3.2 (Millipore).

\section{Quantification of inhibition the uptake by flow cytometry}

To study the cellular uptake mechanisms, HeLa cells growing in a 96 well plate (100.000 cells per well seeded) were treated for $30 \mathrm{~min}$ with the following compounds diluted in DMEM without serum or antibiotics: Dynasore $(80 \mu \mathrm{M})$, chlorpromazine $(30 \mu \mathrm{M})$, methyl- $\beta$-cyclodextrin $(5 \mathrm{mM})$, Wortmannin $(200$ $\mathrm{nM})$, EIPA $(50 \mu \mathrm{M})$, heparin $(5 \mu \mathrm{g} / \mathrm{mL})$, chloroquine $(100 \mu \mathrm{M})$ or ammonium chloride $(50 \mathrm{mM})$. For the incubation at low temperature, another plate was incubated on ice and ice-cold solutions were used for the washes and incubations. Cells were then incubated with the TAMRA-labelled peptides in the presence of the same amount of inhibitors in DMEM for $30 \mathrm{~min}$ at $37^{\circ} \mathrm{C}$. Cells were washed twice with HKR and 0.1 $\mathrm{mg} / \mathrm{mL}$ of heparin in HKR and trypsinized. Trypsin was neutralized with $2 \%$ FBS in PBS with $5 \mathrm{mM}$ EDTA and cell fluorescence was measured on a Guava EasyCyte ${ }^{\mathrm{TM}}$ cytometer using a green laser (532 nm) and collecting the emission at 575/25 nm. Cells with typical FSC and SSC parameters were selected and the median fluorescence intensity calculated for each sample (MFI). Each condition was done in triplicate. In the study of the uptake inhibition at different concentrations of the peptide, fluorescence values were normalized to the uptake of each untreated control (100\%) after blank subtraction. In all cases, data analysis was performed with InCyte software included in GuavaSoft 3.2 (Millipore).

\section{Cell viability}

Cell viability was established by a standard MTT assay. One day before the assay, a suspension of HeLa cells was plated in 96-well tissue culture plates (Costar 96 Flat Bottom Transparent Polystyrol) by adding $100 \mu 1(\sim 10.000$ cells $)$ per well. The next day, the medium was aspirated and cells were incubated in DMEM containing 10\% Fetal Bovine Serum (FBS) in the presence of the different peptides $(50 \mu 1 /$ well) at different concentrations $(1,3,4,5,7,10 \mu \mathrm{M})$. After $1 \mathrm{~h}$ of incubation at $37^{\circ} \mathrm{C}$, the viability was measured by quantifying the cellular ability to reduce the water-soluble tetrazolium dye 3-4,5-dimethylthiazole-2,5diphenyl tetrazolium bromide (MTT) to its insoluble formazan salt as follows. MTT $(5 \mathrm{mg} / \mathrm{ml}$ in PBS, 10 $\mu 1 /$ well) was added to the wells and the cells were further incubated for $4 \mathrm{~h}$. The supernatant was carefully removed and the water-insoluble formazan salt was dissolved in DMSO $(100 \mu 1 /$ well $)$. The absorbance at $570 \mathrm{~nm}$ was measured. Data points were collected in triplicate and expressed as normalized values for untreated as control cells (100\%) after blank subtraction. 


\section{Peptide stability in serum}

To determine the half-life of $\mathbf{P}_{\mathbf{8}}$ in serum, the peptide was dissolved in FBS at a final concentration of 100 $\mu \mathrm{M}$ and incubated at $37{ }^{\circ} \mathrm{C}$. At different time points, $40 \mu \mathrm{L}$ aliquots were taken. Samples were mixed with an equal volume of acetonitrile and centrifuged for $5 \mathrm{~min}$ at $10000 \mathrm{rpm}$ to remove most serum proteins. Supernatants were freeze-dried and resuspended in $50 \mu \mathrm{L}$ Milli-Q water, before quantitation by HPLC, measuring TAMRA absorbance at $555 \mathrm{~nm}$ [RP-HPLC Agilent SB-C18 column, $\mathrm{H}_{2} \mathrm{O}(0.1 \% \mathrm{TFA}) / \mathrm{CH}_{3} \mathrm{CN}$ $(0.1 \%$ TFA) $95: 5 \rightarrow 5: 95(0 \rightarrow 20 \mathrm{~min})]$. 


\section{Supporting figures}

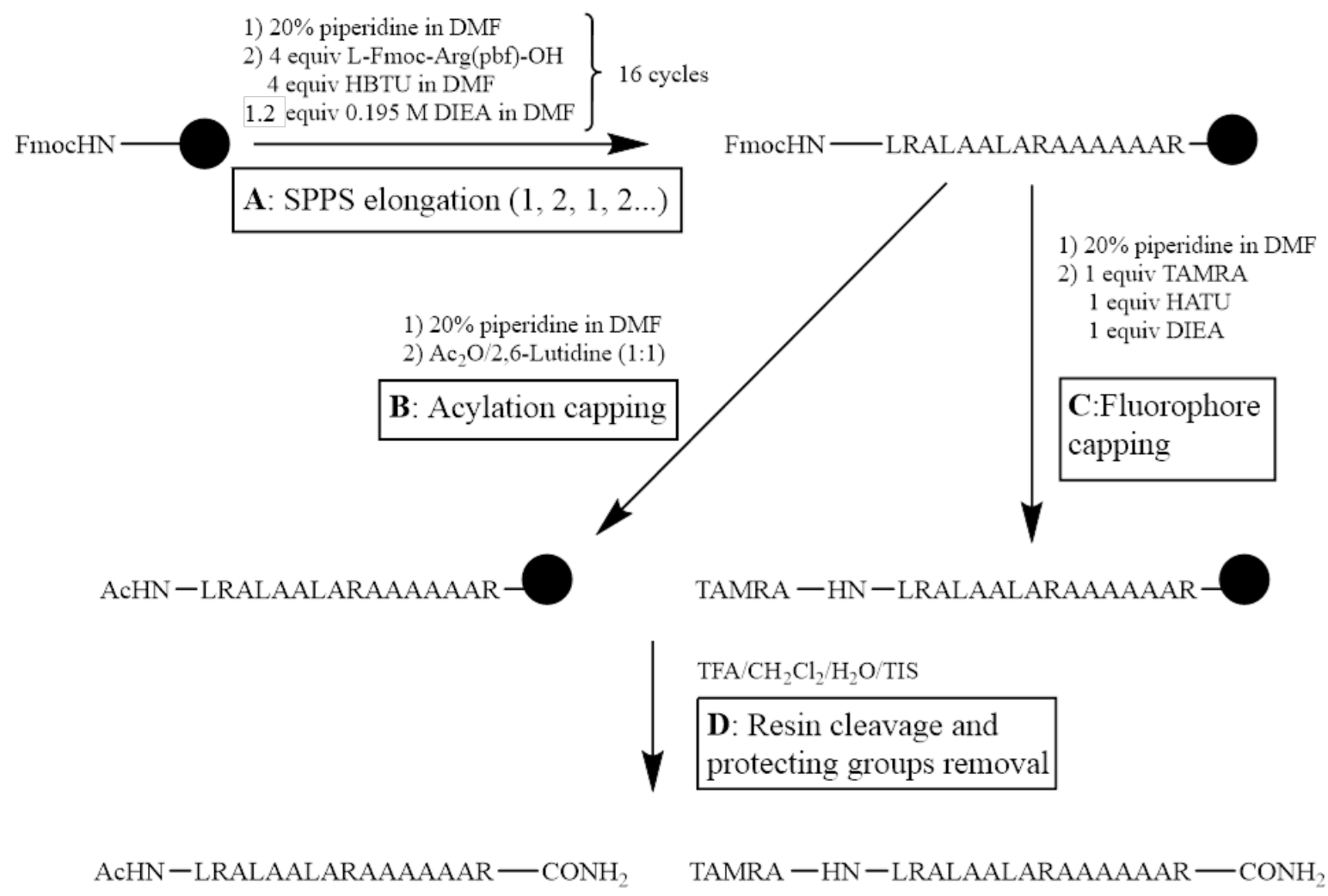

Figure S1: General synthetic scheme for the solid phase peptide synthesis (SPPS). 

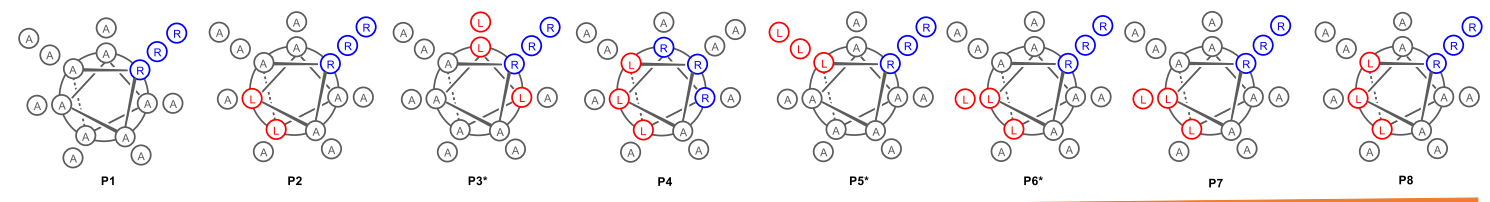
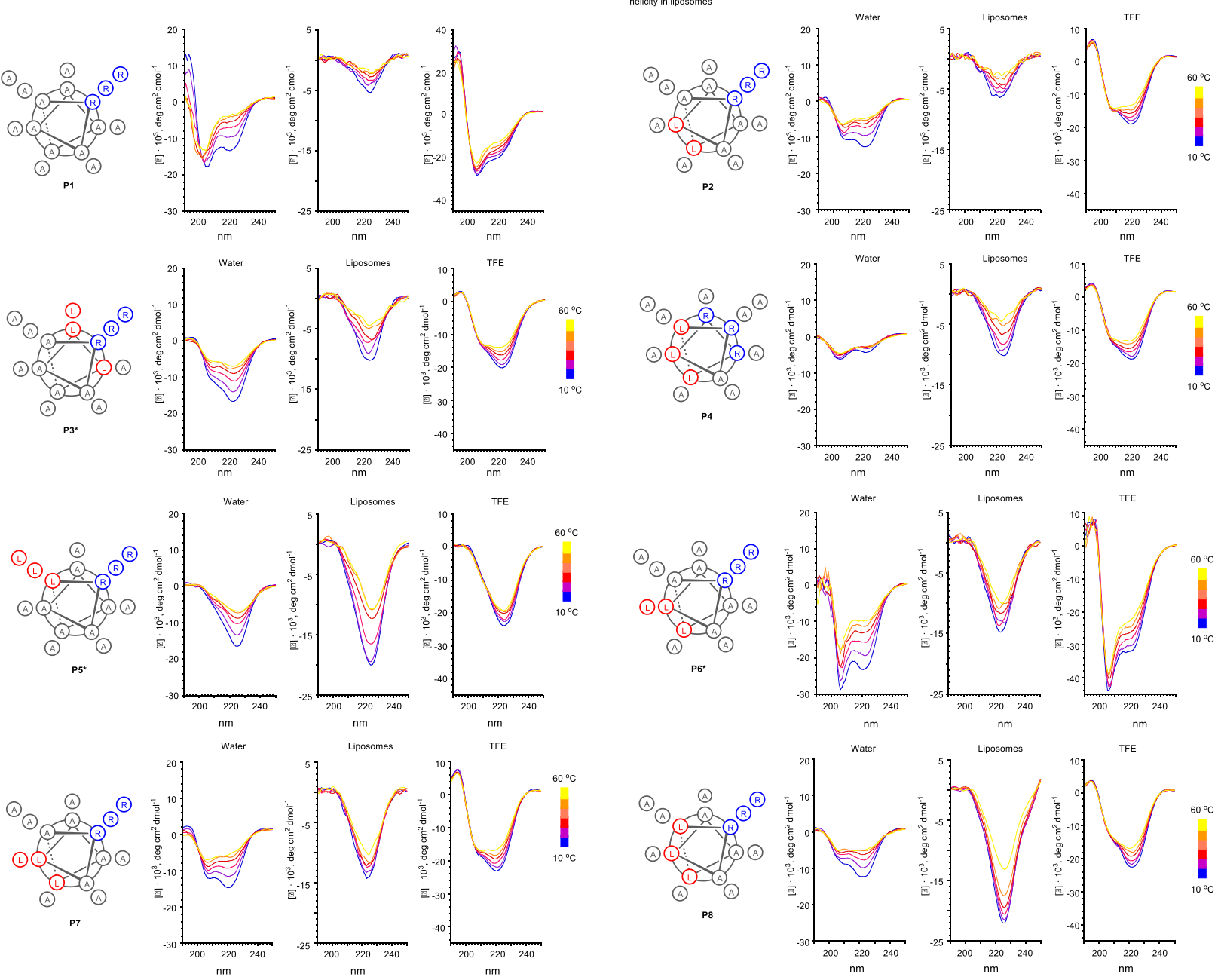

Figure S2: A) Heptad structures of the peptides ordered by increased helicity in liposomes. B) Circular dichroism in HKR buffer, liposomes and TFE (from left to right) of all peptides. The measurements were taken at different temperatures $\left(10-60{ }^{\circ} \mathrm{C}\right)$. All samples were at $100 \mu \mathrm{M}$ peptide final concentration. 


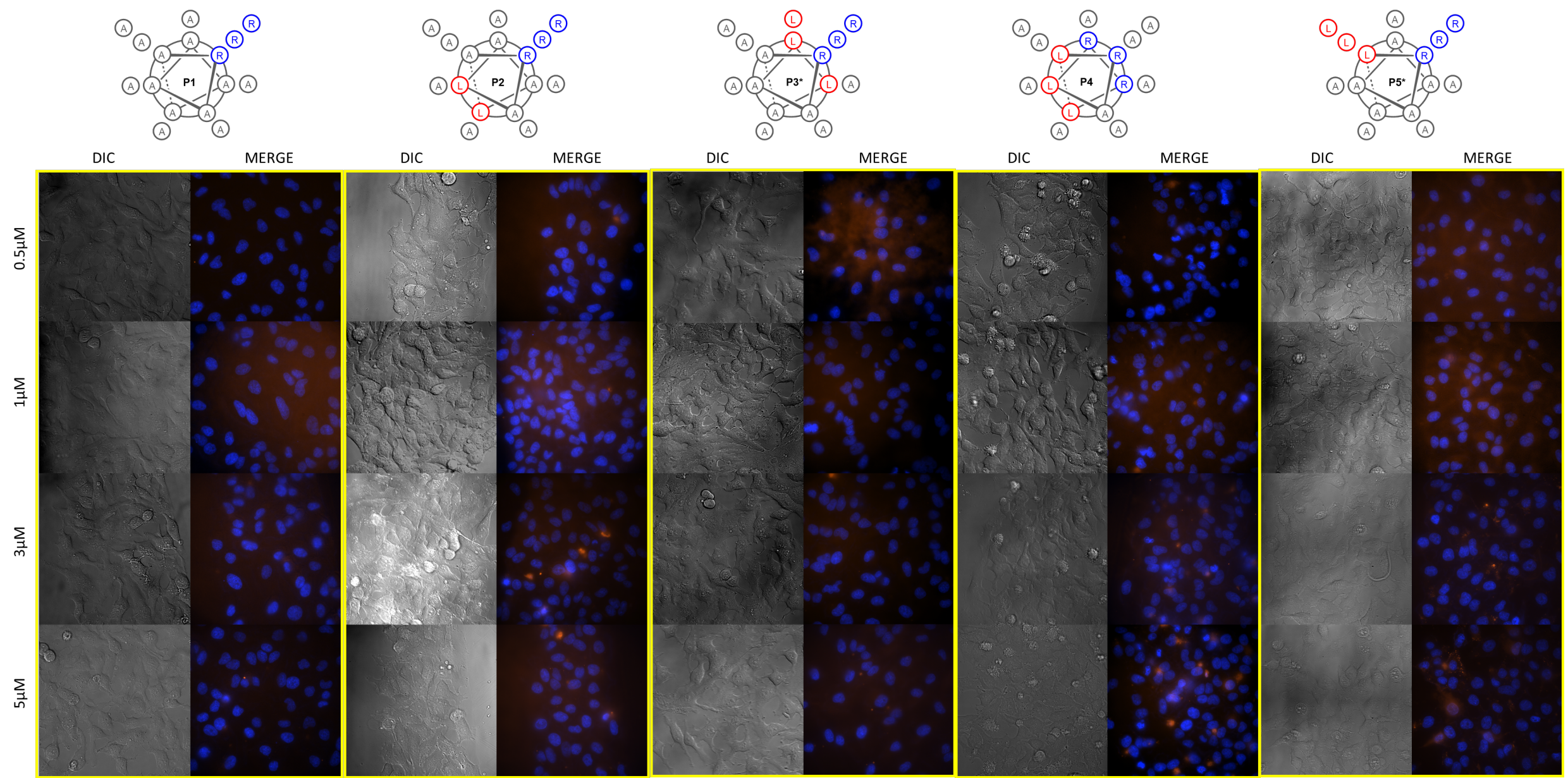

Figure S3: Epifluorescence image of peptides in HeLa cells. $\mathbf{P}_{1}, \mathbf{P}_{2}, \mathbf{P}_{3^{*}}, \mathbf{P}_{4}$ and $\mathbf{P}_{5^{*}}$. DIC on the left and merge channels (peptide and nuclei) on the right. HeLa cells were treated first with Hoechst 33342 for 30 min, washed (HKR buffer, 1x) and then incubated with the peptides $(0.5,1,3$ and $5 \mu \mathrm{M})$ in HKR buffer for 30 min. The cells were finally washed (HKR buffer, $3 \mathrm{x}$ ) and then observed with the epifluorescence microscope. 


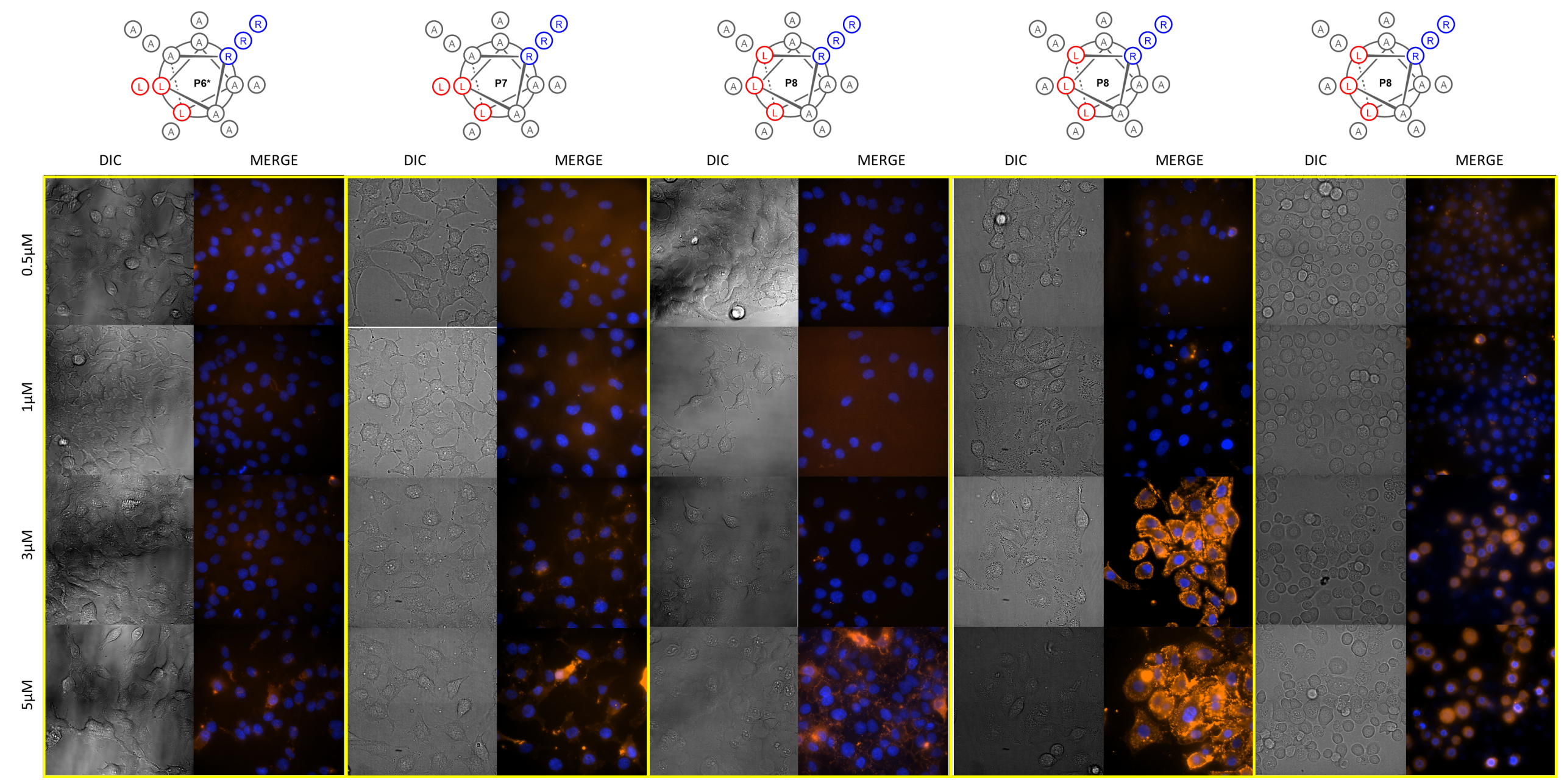

Figure S4: Epifluorescence image of peptides in HeLa cells. $\mathbf{P}_{\mathbf{6}}$ in HeLa cells; $\mathbf{P}_{7}$ in HeLa cells; $\mathbf{P}_{\mathbf{8}}$ in HeLa cells; $\mathbf{P}_{\mathbf{8}}$ in A-549 cells; $\mathbf{P}_{\mathbf{8}}$ in SF9 cells. DIC on the left and merge channels (peptide and nuclei) on the right. HeLa cells were treated first with Hoechst 33342 for 30 min, washed (HKR buffer, 1x) and then incubated with the peptides $(0.5,1,3$ and $5 \mu \mathrm{M})$ in HKR buffer for $30 \mathrm{~min}$. The cells were finally washed (HKR buffer, $3 \mathrm{x}$ ) and then observed with the epifluorescence microscope. In the case of SF9 the buffer used was Sf-900-II. 


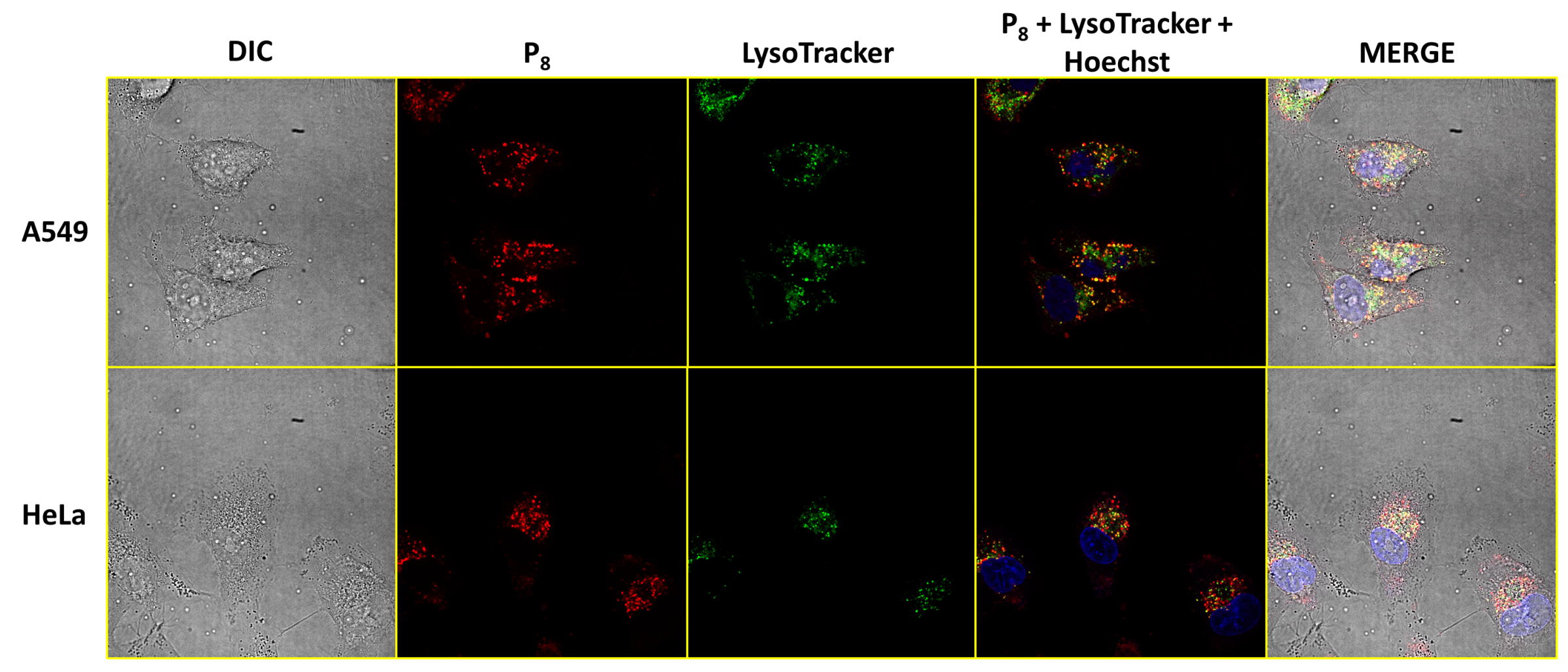

Figure S5: LysoTracker colocalization studies. HeLa cells and A549 cells were incubated with $5 \mu \mathrm{M} \mathbf{P}_{\mathbf{8}}$ peptide for 30 min in HKR, washed and incubated with DMEM with $10 \%$ serum for $3 \mathrm{~h}$. Lysosomes were stained with $50 \mathrm{nM}$ LysoTracker Deep Red the last 30 min of incubation before imaging in a confocal microscope. $\mathbf{P}_{\mathbf{8}}$ is shown in red, LysoTracker is shown in green. Nuclei were counterstained blue with Hoechst. 


\section{Inhibition cytometry}

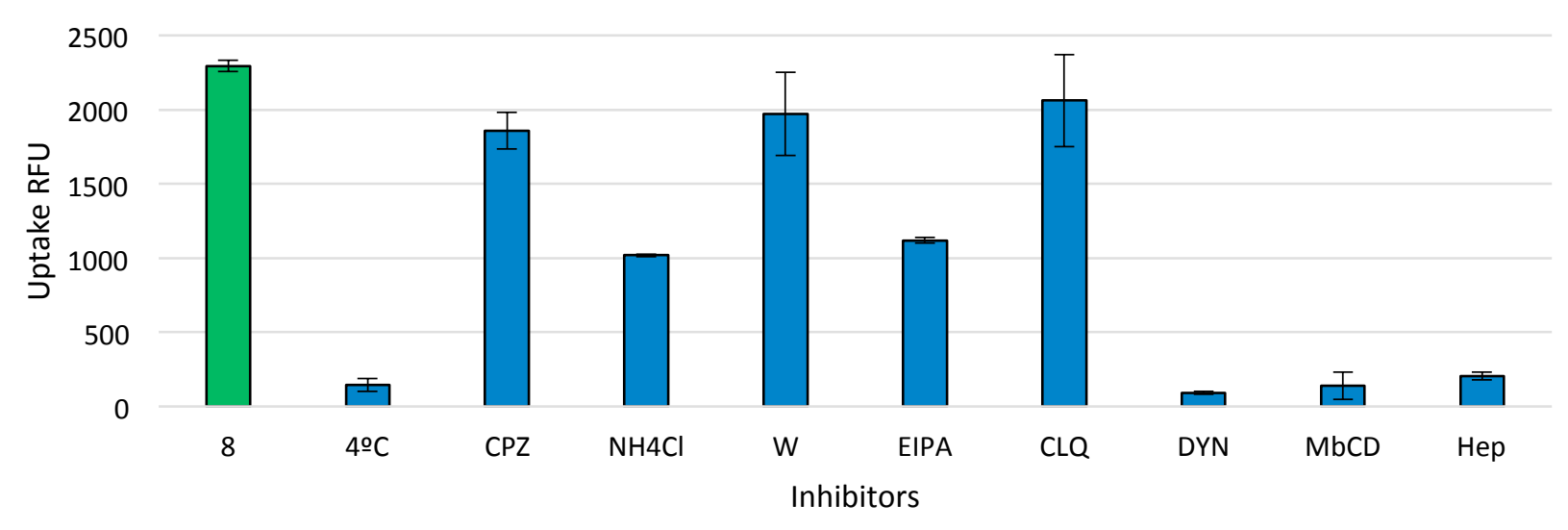

B)

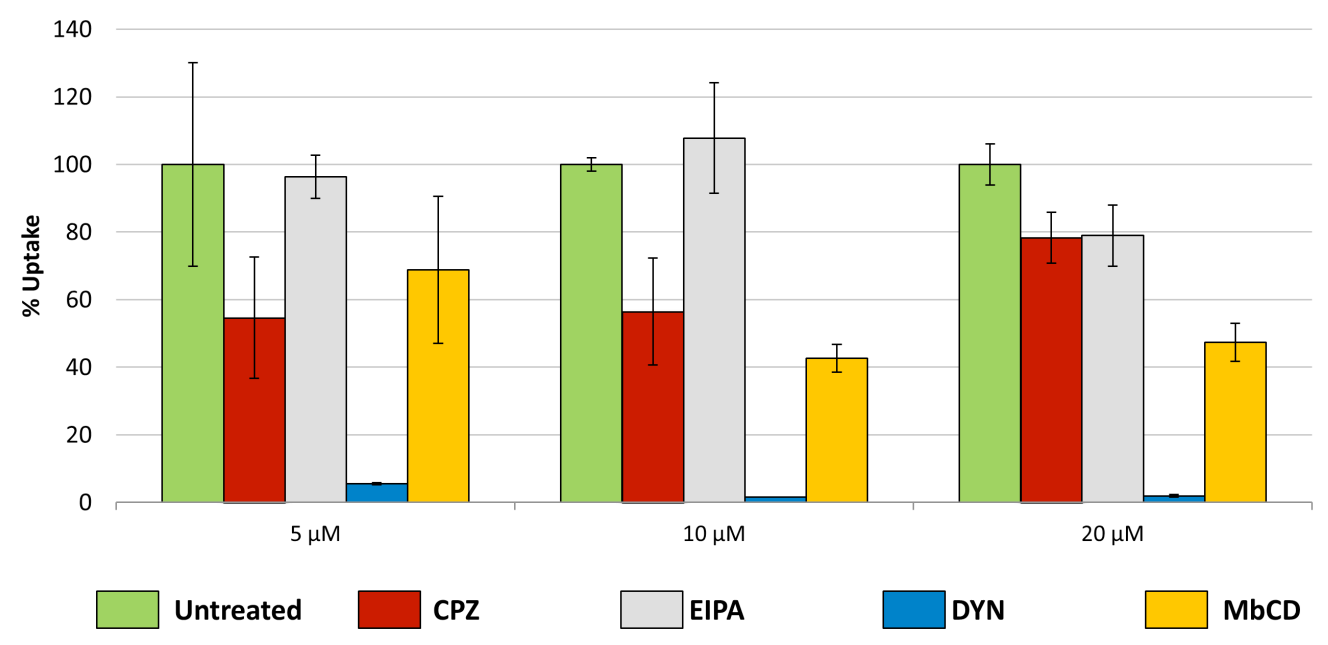

Figure S6: A) Histogram of the uptake in relative fluorescence units (RFU) for $\mathbf{P}_{\mathbf{8}}(5 \mu \mathrm{M})$ in the presence of different endocytic inhibitors. In the histogram, the green column is the peptide alone, and the blue columns are the uptake in the presence of the inhibitors: $4^{\circ} \mathrm{C}, \mathrm{CPZ}$ : chlorpromazine; $\mathrm{NH} 4 \mathrm{Cl}$ : Ammonium Chloride; W: Wortmannin; EIPA: 5-( $N$-Ethyl- $N$-isopropyl)amiloride; CLQ: chloroquine; DYN: Dynasore; M $\beta C D$ : methyl- $\beta$-cyclodextrin; Hep: heparin. Error bars indicate SD of three replicates. Hela cells were treated in DMEM (-) for 30 min prior to trypsinization and cytometry quantification. B) Study of the endocytic mechanism at different peptide concentrations. HeLa cells were treated with the indicated inhibitors for $30 \mathrm{~min}$ in DMEM (-) before incubating with the peptide $\mathbf{P}_{\mathbf{8}}$ at different concentrations for $30 \mathrm{~min}$. Cells were then trypsinized and analyzed by flow cytometry. Error bars indicate SD of three replicates. 


\section{Internalization in HeLa - A549 - SF9}

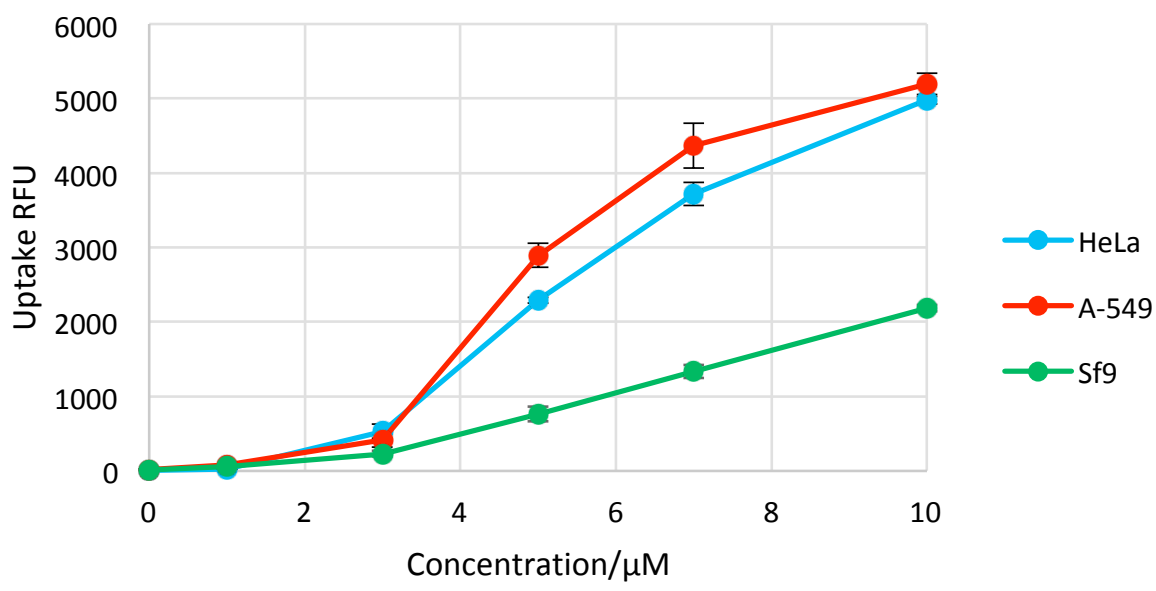

Figure S7: Uptake quantification by flow cytometry of the peptide $\mathbf{P}_{\mathbf{8}}$ in three different cell lines: HeLa cells in blue, A-549 cells in red and SF9 cells in green. The points were collected at six different concentrations $(0,1,3,5,7,10 \mu \mathrm{M})$. Cells were treated in DMEM (-) or Sf-900-II in the case of Sf9 cells for 1 hour prior to trypsinization and cytometry quantification. Error bars indicate SD of three replicates. 

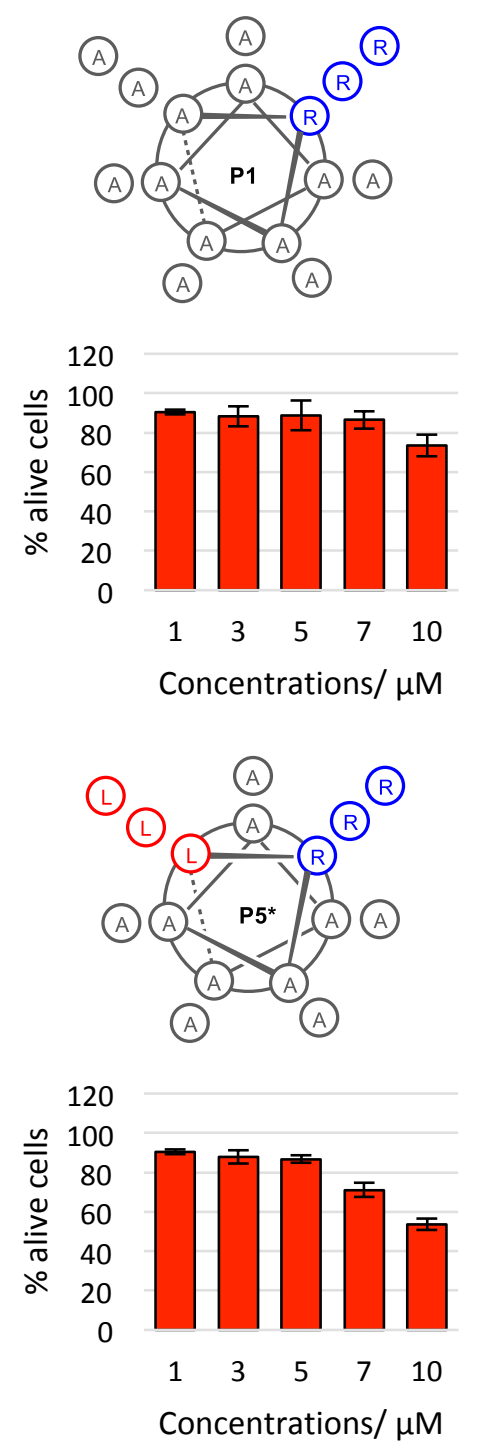
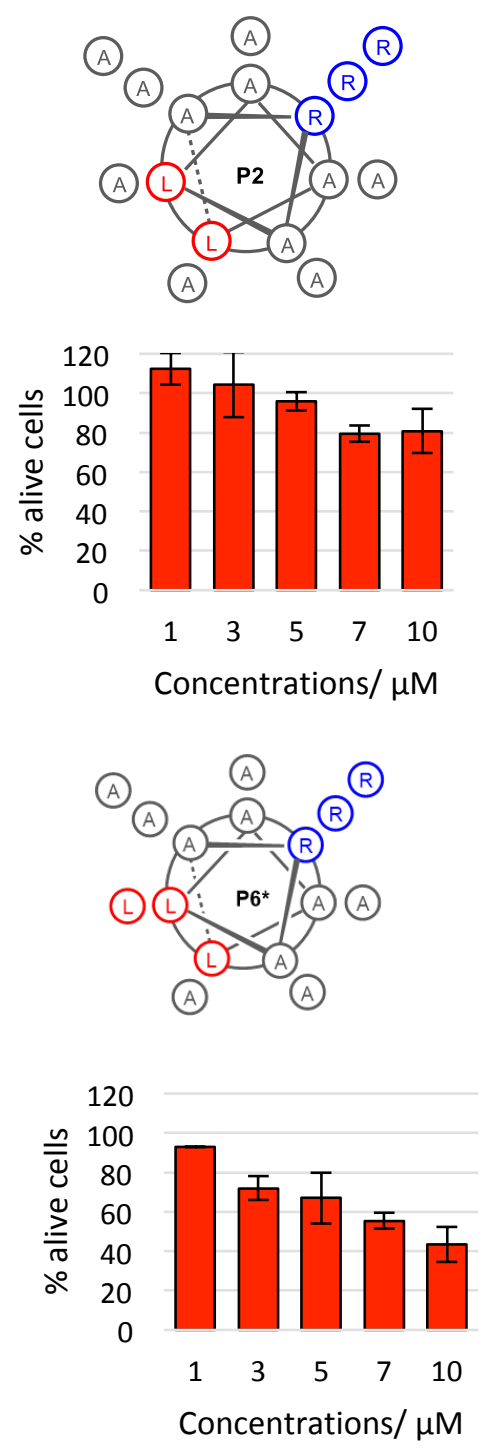
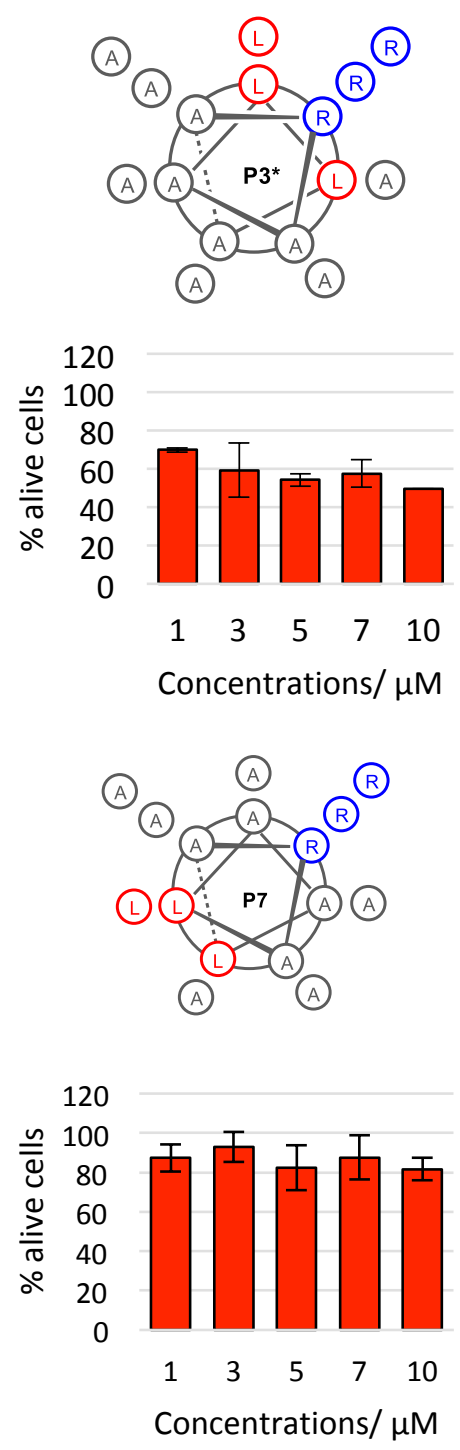

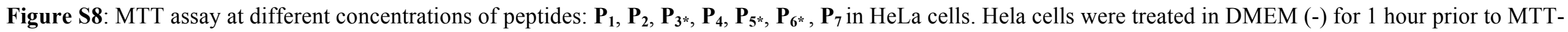
assay. 


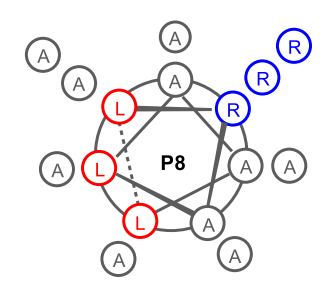

HeLa-P8

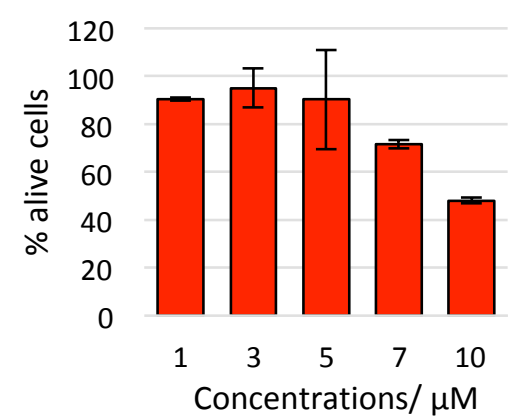

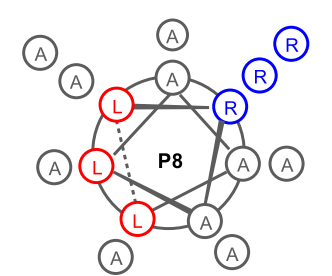

A-549-P8

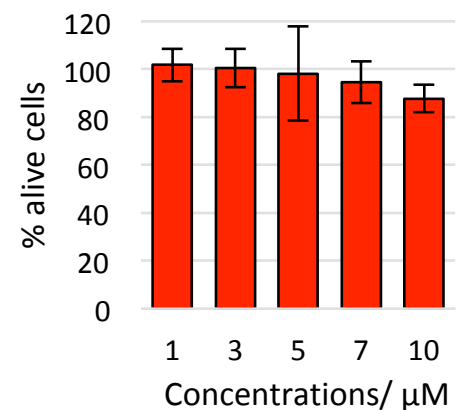

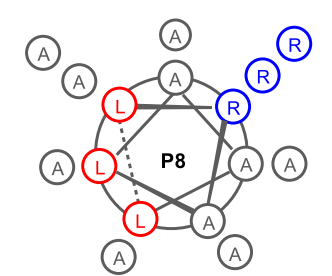

SF9-P8

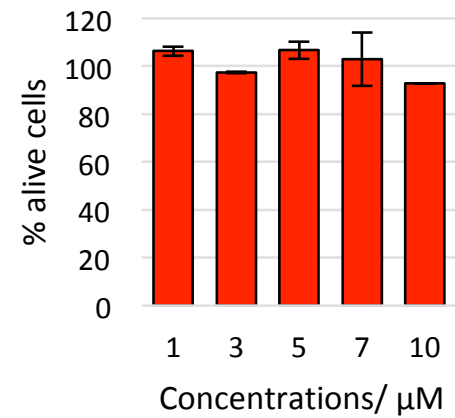

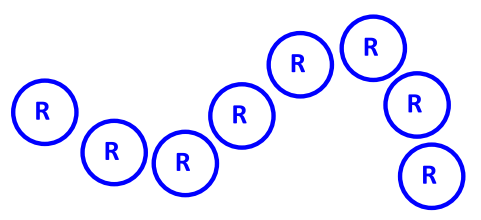

R8

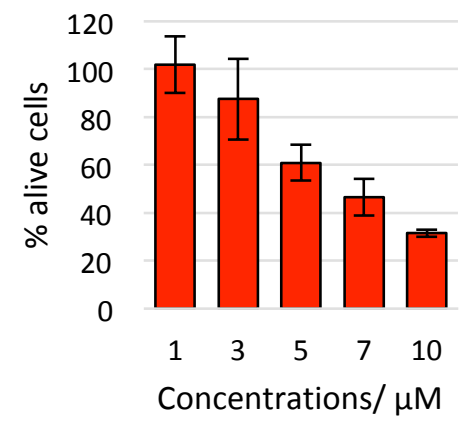

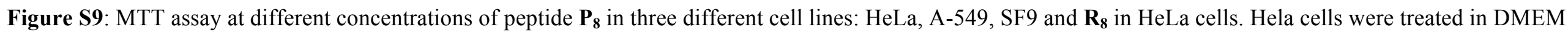
(-) for 1 hour prior to MTT-assay. 


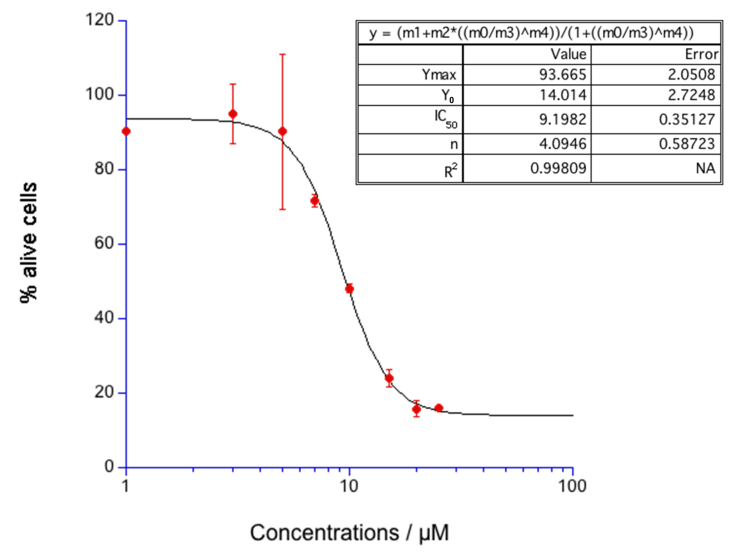

Figure S10: MTT assay at increasing concentrations of $\mathbf{P}_{\mathbf{8}}$ in HeLa cells. Cells were incubated for $1 \mathrm{~h}$ with the peptide in DMEM (-) before MTT assay. Curve fitting was done with KaleidaGraph software, using a 4parameters logistic model. $\mathbf{I C}_{\mathbf{5 0}}=9.2 \mu \mathrm{M}$.

A)

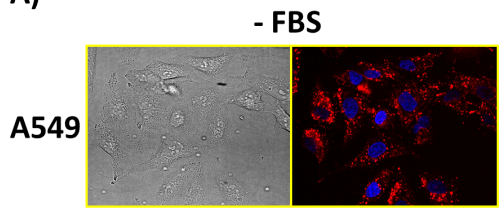

HeLa

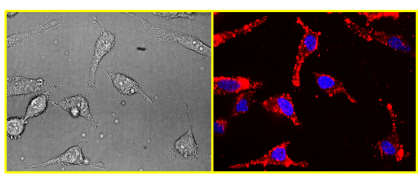

C)

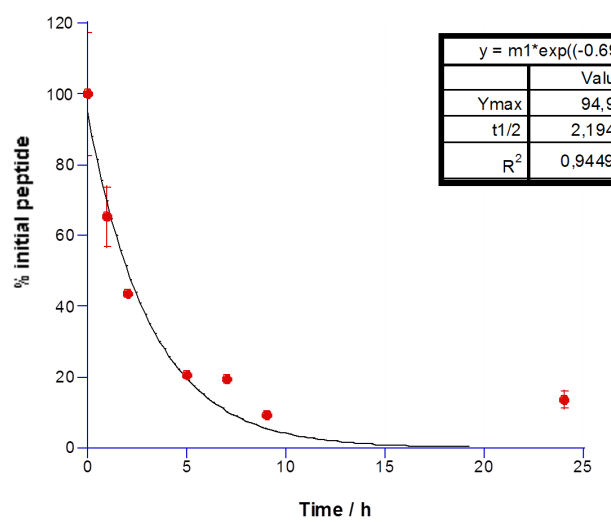

+ FBS
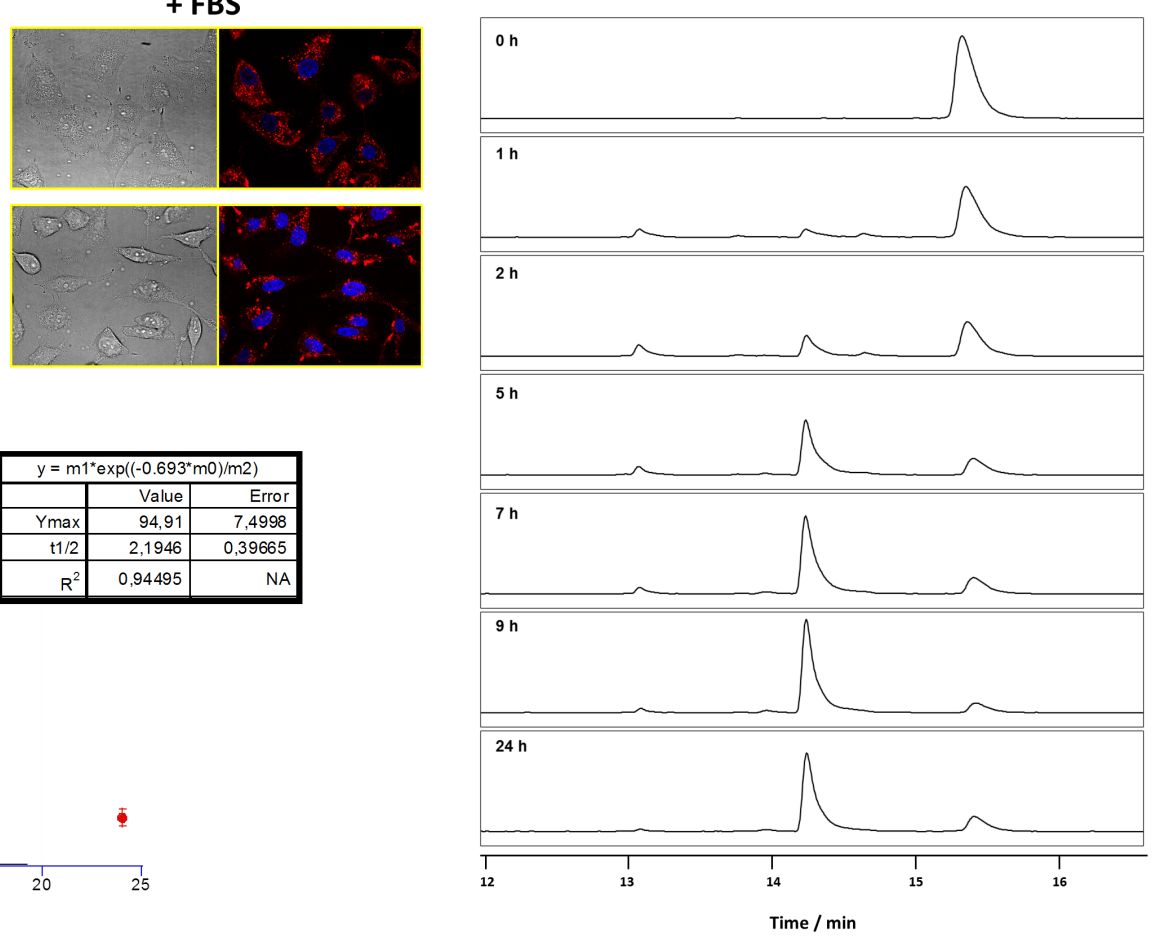

Figure S11: Stability in the presence of serum. A) A-549 and HeLa cells were incubated for 30 min with 5 $\mu \mathrm{M}$ disolved in DMEM (-) or DMEM supplemented with $10 \%$ FBS. Cells were then washed three times with DMEM (-) and imaged in a confocal microscope. B) RP-HPLC of $\mathbf{P}_{\mathbf{8}}$ after different incubation times with FBS (555 nm absorbance) C) Calculation of $\mathbf{P}_{\mathbf{8}}$ half-life in serum. Area of the peak corresponding to the intact peptide was measured for all the time points and normalized to time $0 \mathrm{~h}(100 \%)$. Data was adjusted to an exponential decay curve using KaleidaGraph. $\mathbf{P}_{\mathbf{8}}$ half-life $\sim 2.2 \mathrm{~h}$. 


\section{Supporting figures of Characterization}

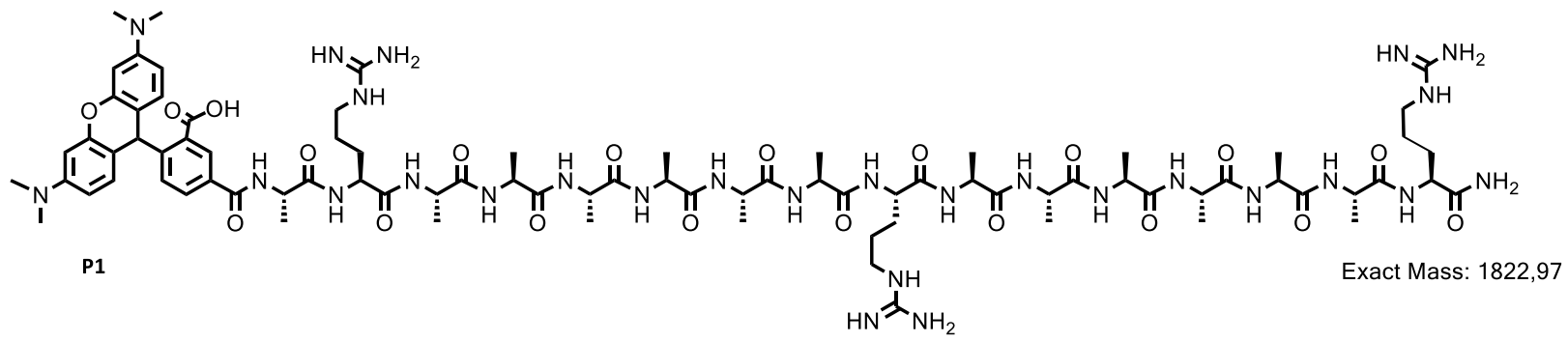

Abs $222 \mathrm{~nm}$ (a.u.)
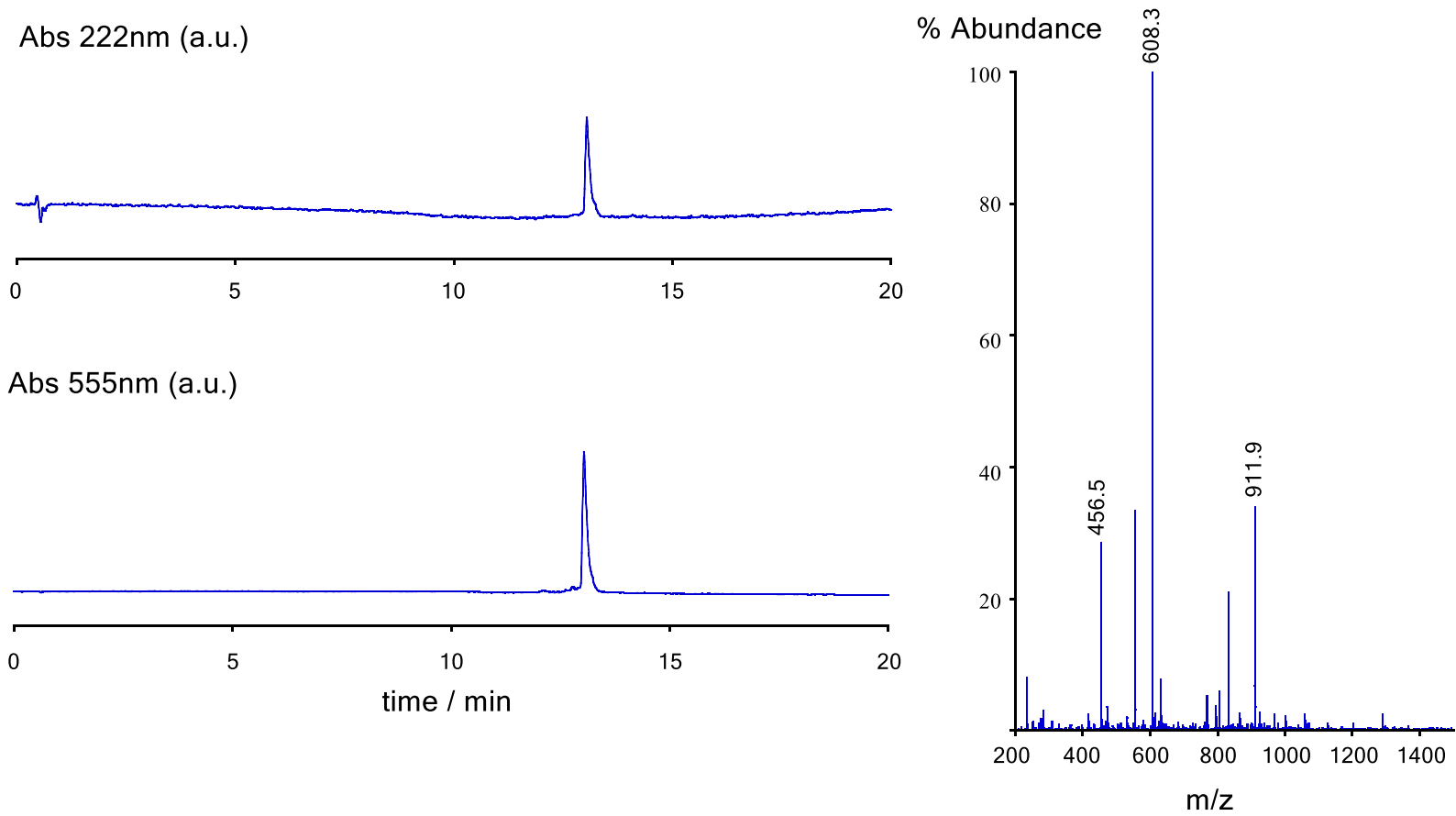

Figure S12: RP-HPLC [Agilent SB-C18 column, $\mathrm{H}_{2} \mathrm{O}(0.1 \%$ TFA $) / \mathrm{CH}_{3} \mathrm{CN}(0.1 \%$ TFA) 95:5 $\rightarrow$ 5:95 $(0 \rightarrow 20 \mathrm{~min})]\left(R_{\mathrm{t}} 13 \mathrm{~min}\right)$ absorbance at $222 \mathrm{~nm}$ and $555 \mathrm{~nm}$ and ESI-MS for Peptide $\mathbf{P}_{\mathbf{1}}$. 


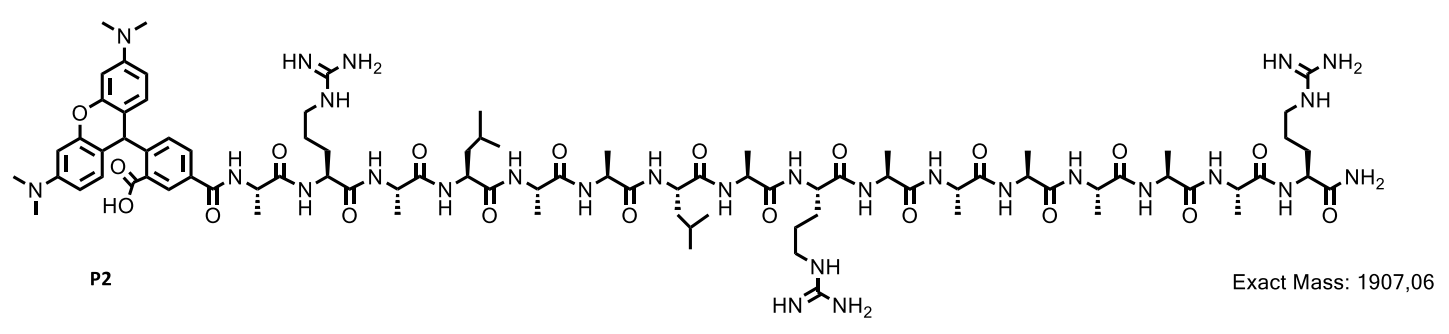

Abs 222nm (a.u.)

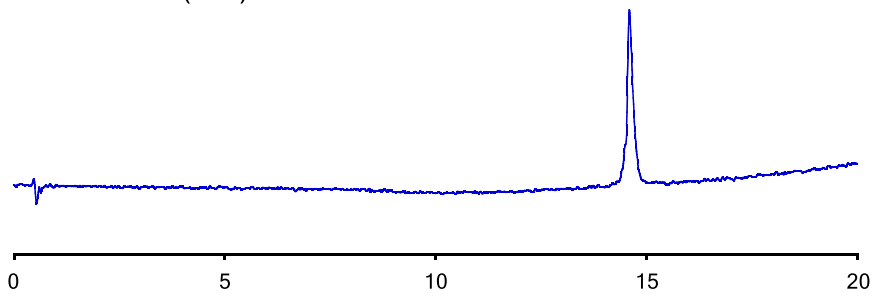

\% Abundance हैं

Abs 555nm (a.u.)
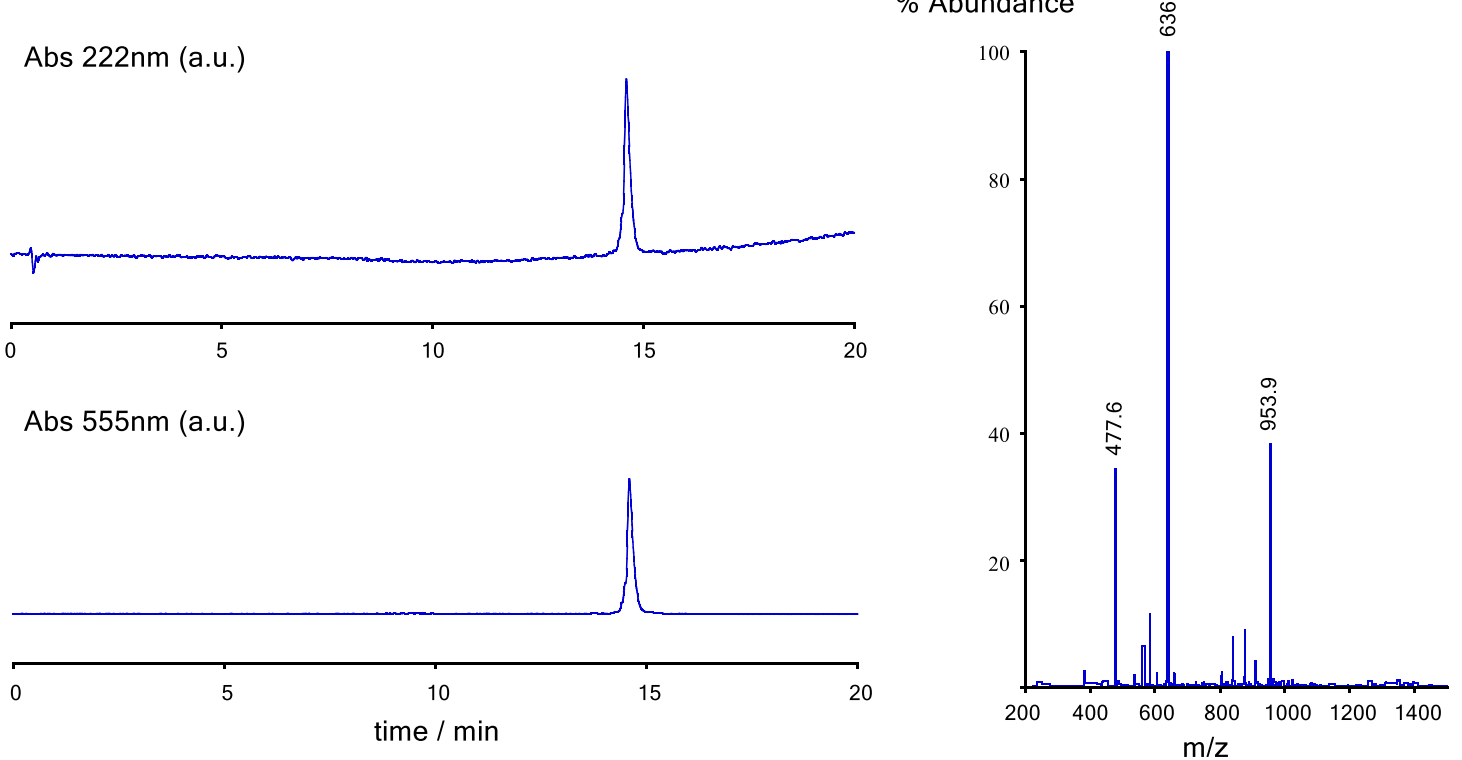

Figure S13: RP-HPLC [Agilent SB-C18 column, $\mathrm{H}_{2} \mathrm{O}(0.1 \%$ TFA $) / \mathrm{CH}_{3} \mathrm{CN}(0.1 \%$ TFA $)$ 95:5 $\rightarrow 5: 95$ $(0 \rightarrow 20 \mathrm{~min})]\left(R_{\mathrm{t}} 14.6 \mathrm{~min}\right)$ absorbance at $222 \mathrm{~nm}$ and $555 \mathrm{~nm}$ and ESI-MS for Peptide $\mathbf{P}_{2}$.

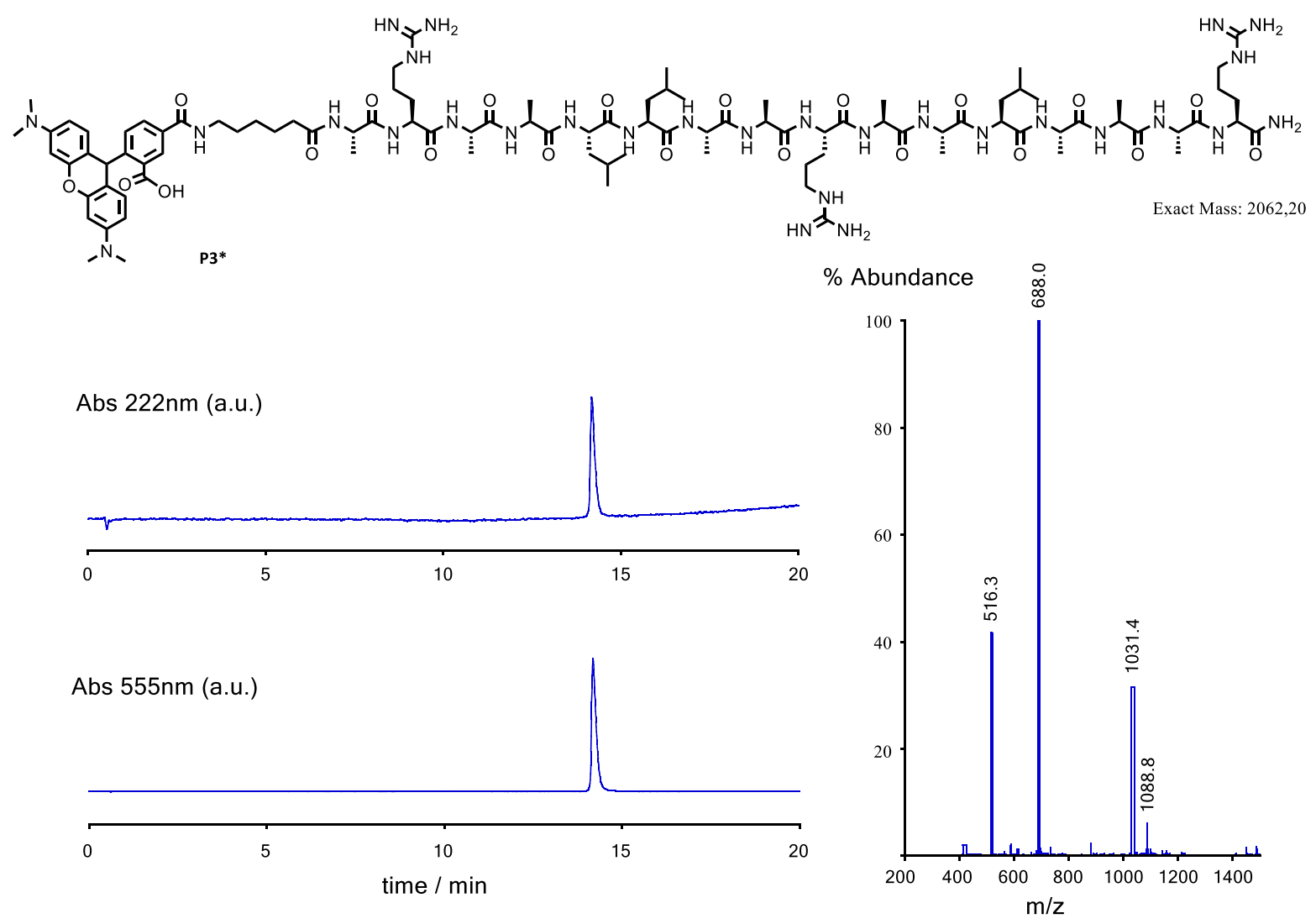

Figure S14: RP-HPLC [Agilent SB-C18 column, $\mathrm{H}_{2} \mathrm{O}(0.1 \%$ TFA $) / \mathrm{CH}_{3} \mathrm{CN}(0.1 \%$ TFA) 95:5 $\rightarrow 5: 95$ $(0 \rightarrow 20 \mathrm{~min})]\left(R_{\mathrm{t}} 14.2 \mathrm{~min}\right)$ absorbance at $222 \mathrm{~nm}$ and $555 \mathrm{~nm}$ and ESI-MS for Peptide $\mathbf{P}_{3^{*}}$. 

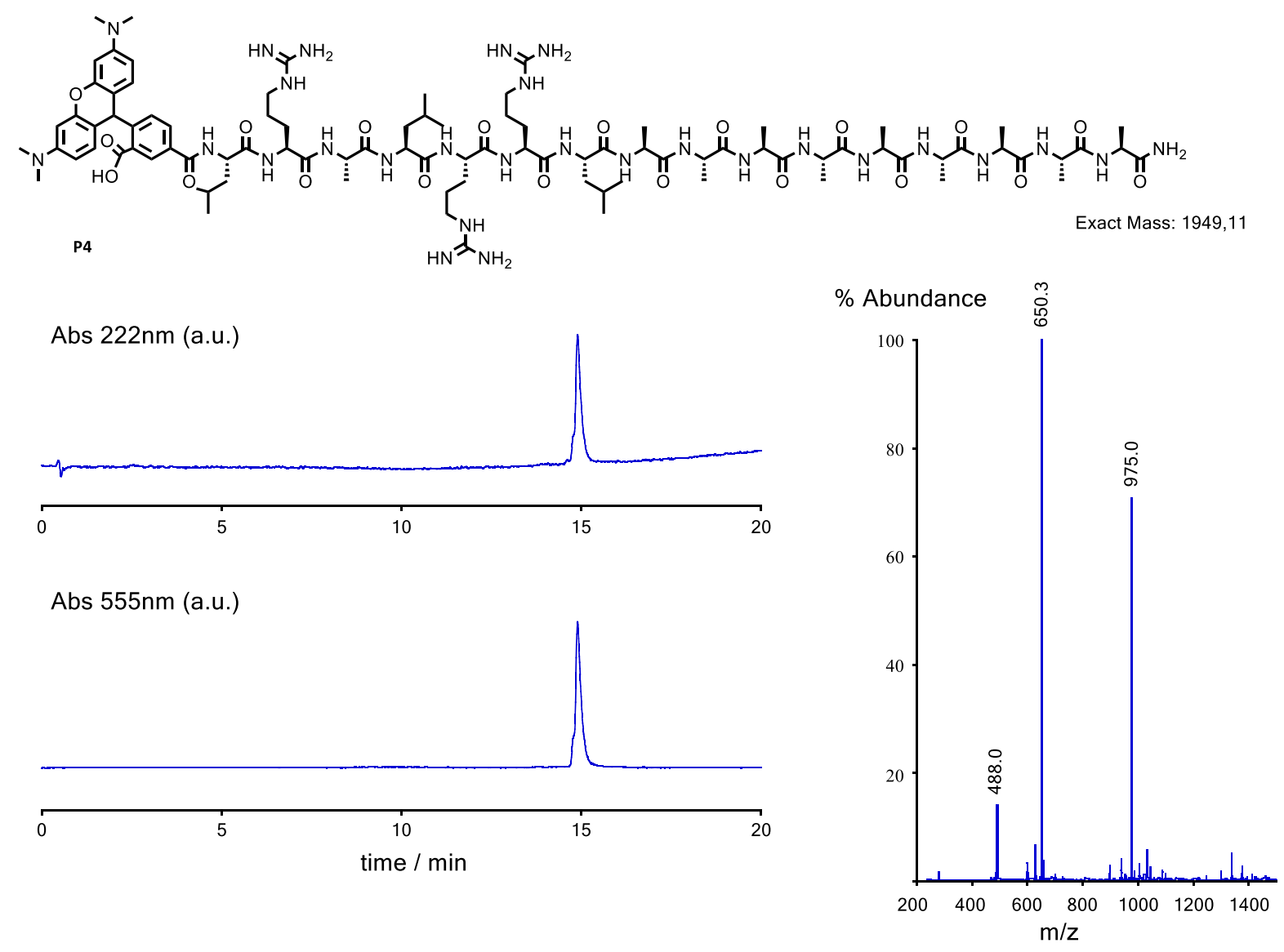

Abs 555nm (a.u.)

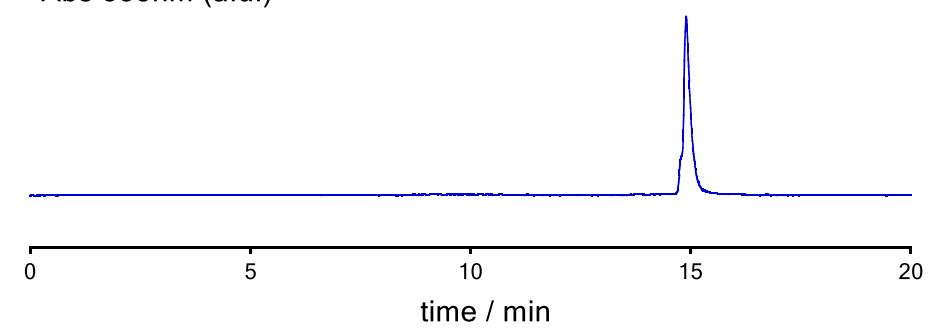

Figure S15: RP-HPLC [Agilent SB-C18 column, $\mathrm{H}_{2} \mathrm{O}(0.1 \%$ TFA $) / \mathrm{CH}_{3} \mathrm{CN}(0.1 \%$ TFA $)$ 95:5 $\rightarrow 5: 95$ $(0 \rightarrow 20 \mathrm{~min})]\left(R_{\mathrm{t}} 14.9 \mathrm{~min}\right)$ absorbance at $222 \mathrm{~nm}$ and $555 \mathrm{~nm}$ and ESI-MS for Peptide $\mathbf{P}_{4}$.

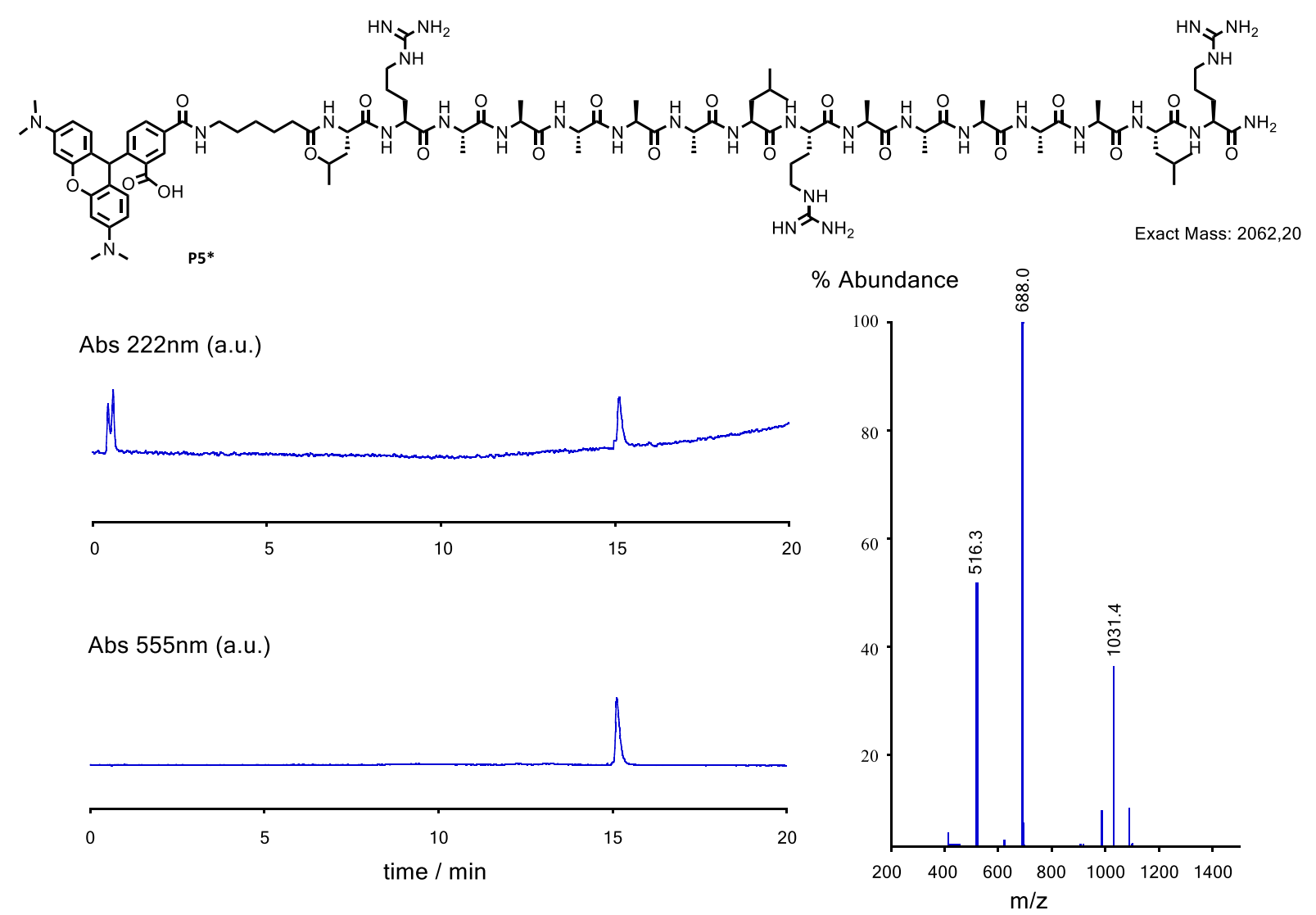

Figure S16: RP-HPLC [Agilent SB-C18 column, $\mathrm{H}_{2} \mathrm{O}(0.1 \%$ TFA $) / \mathrm{CH}_{3} \mathrm{CN}(0.1 \%$ TFA) 95:5 $\rightarrow$ 5:95 $(0 \rightarrow 20 \mathrm{~min})]\left(R_{\mathrm{t}} 15.2 \mathrm{~min}\right)$ absorbance at $222 \mathrm{~nm}$ and $555 \mathrm{~nm}$ and ESI-MS for Peptide $\mathbf{P}_{5^{*}}$ 

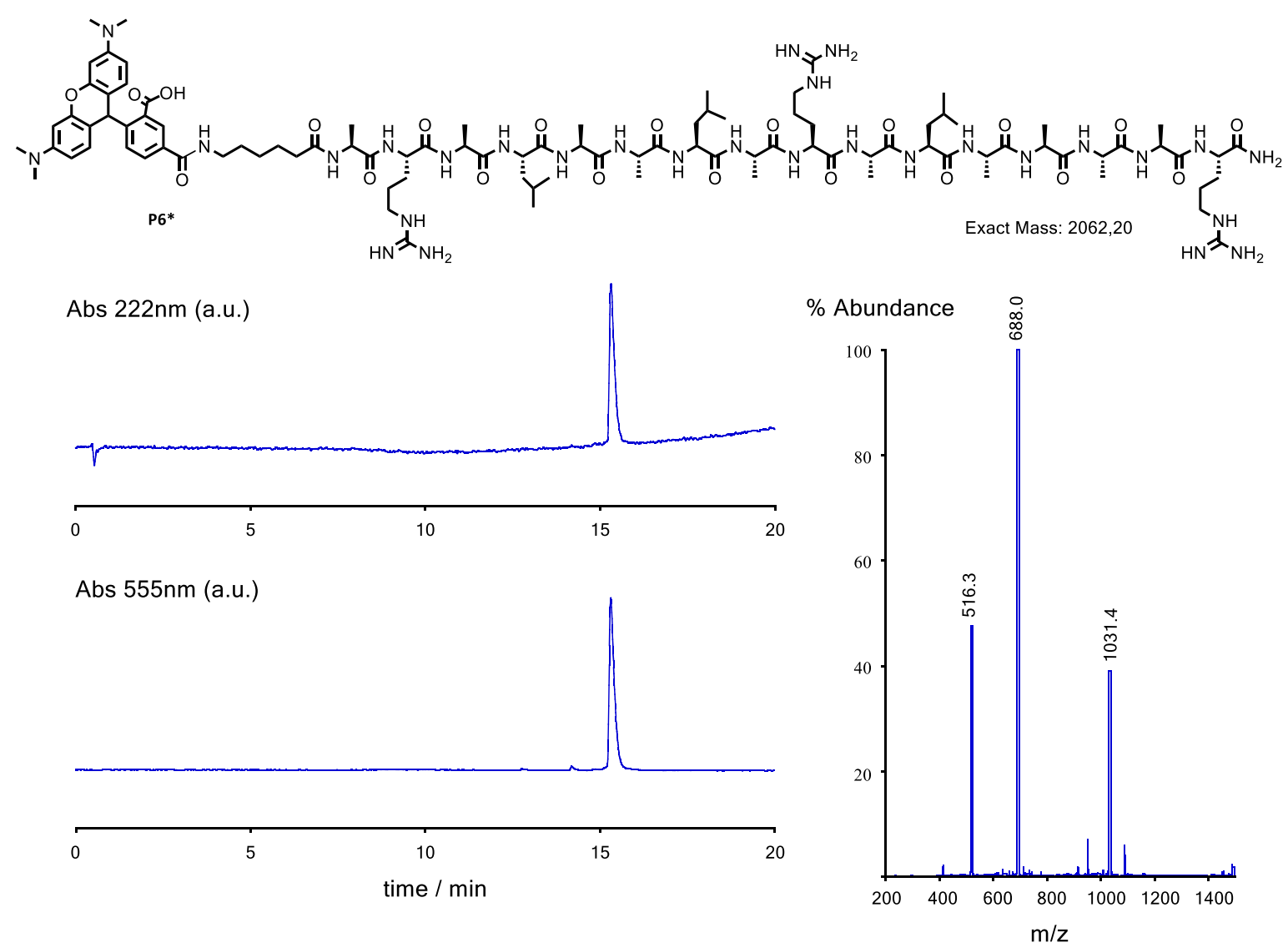

Figure S17: RP-HPLC [Agilent SB-C18 column, $\mathrm{H}_{2} \mathrm{O}(0.1 \%$ TFA $) / \mathrm{CH}_{3} \mathrm{CN}(0.1 \%$ TFA) 95:5 $\rightarrow$ 5:95 $(0 \rightarrow 20 \mathrm{~min})]\left(R_{\mathrm{t}} 15.3 \mathrm{~min}\right)$ absorbance at $222 \mathrm{~nm}$ and $555 \mathrm{~nm}$ and ESI-MS for Peptide $\mathbf{P}_{\mathbf{6}^{*}}$.

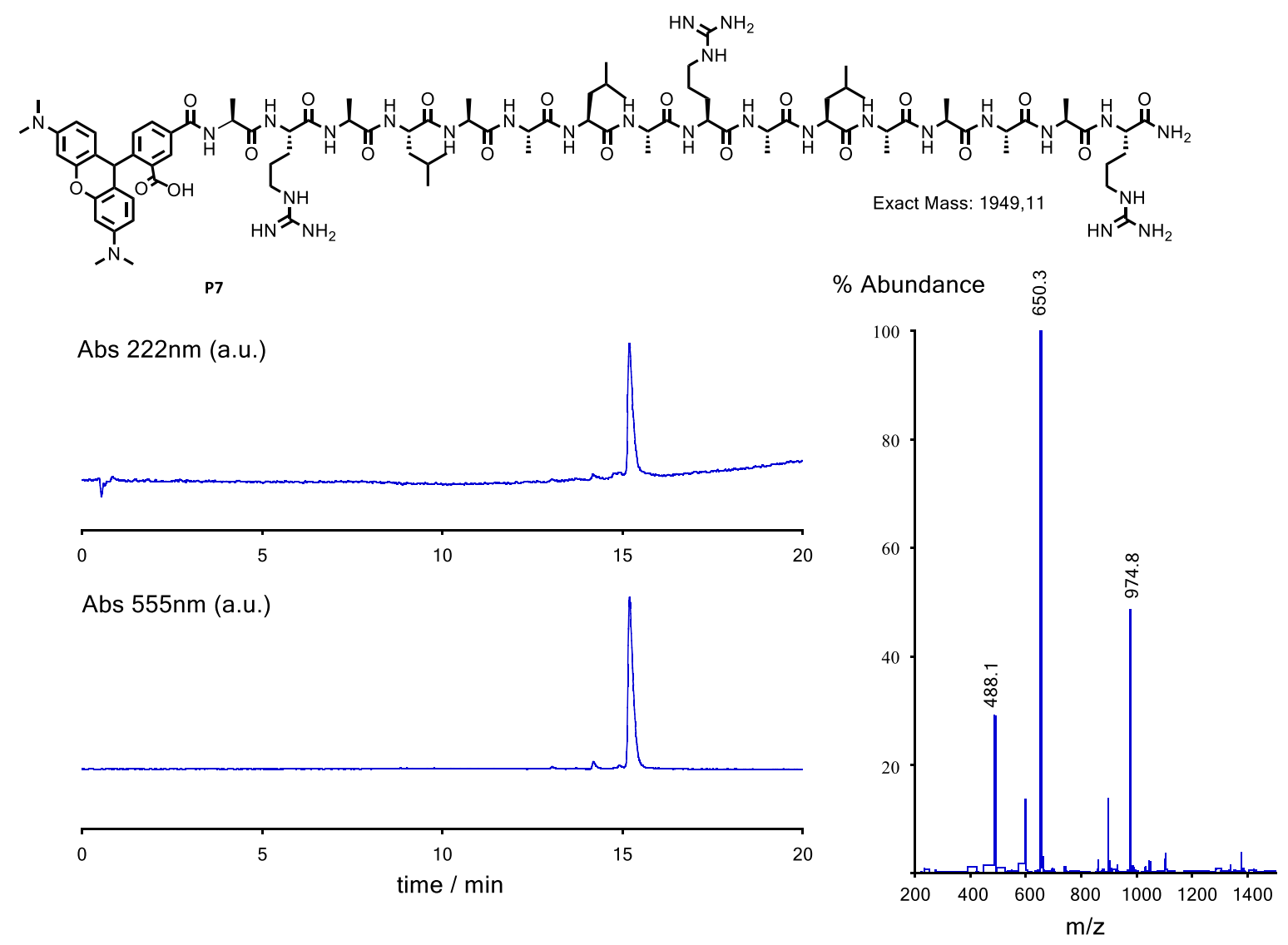

Figure S18: RP-HPLC [Agilent SB-C18 column, $\mathrm{H}_{2} \mathrm{O}(0.1 \%$ TFA $) / \mathrm{CH}_{3} \mathrm{CN}(0.1 \%$ TFA) 95:5 $\rightarrow$ 5:95 $(0 \rightarrow 20 \mathrm{~min})]\left(R_{\mathrm{t}} 15.5 \mathrm{~min}\right)$ absorbance at $222 \mathrm{~nm}$ and $555 \mathrm{~nm}$ and ESI-MS for Peptide $\mathbf{P}_{7}$. 

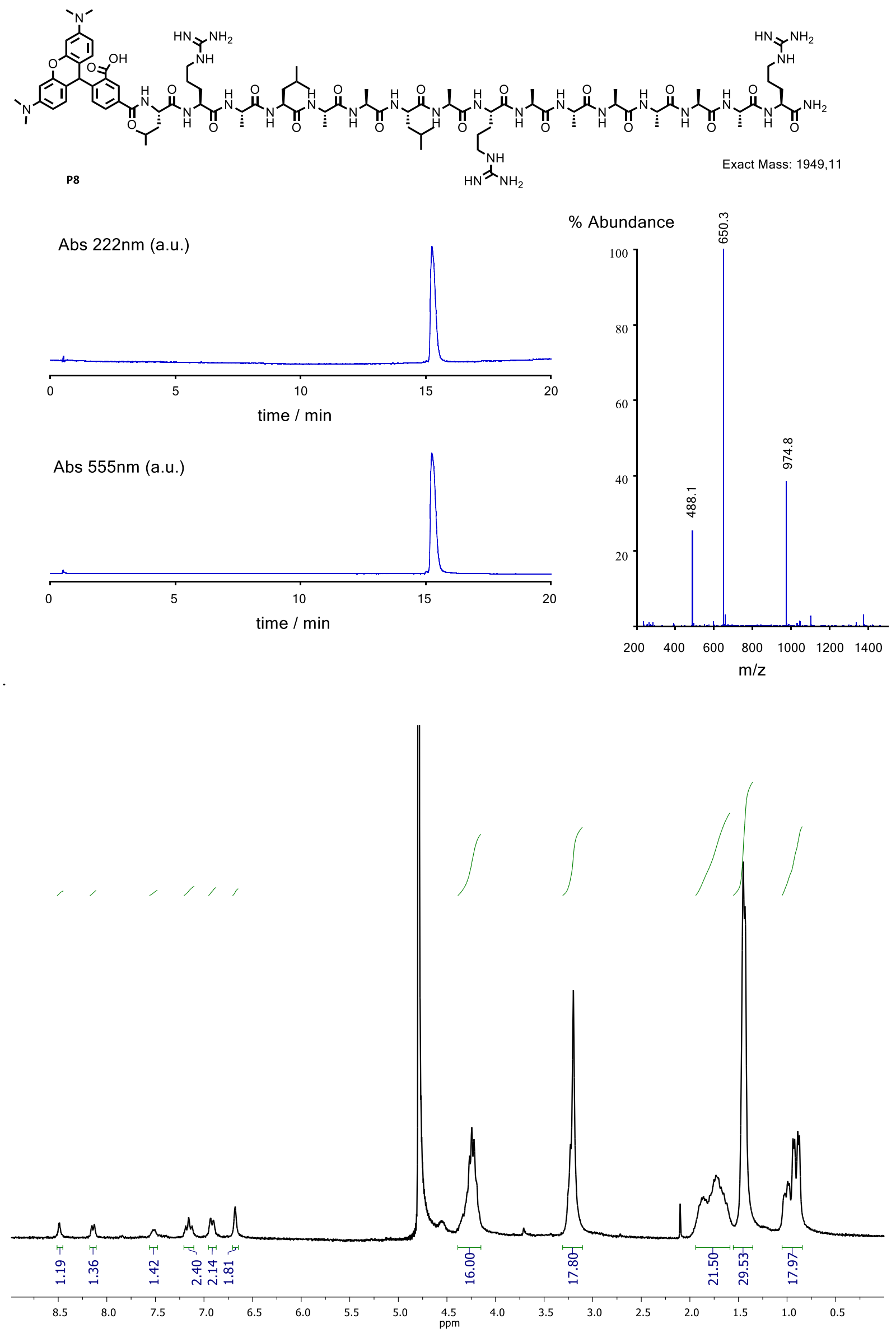

Figure S19: RP-HPLC [Agilent SB-C18 column, $\mathrm{H}_{2} \mathrm{O}\left(0.1 \%\right.$ TFA)/ $\mathrm{CH}_{3} \mathrm{CN}(0.1 \%$ TFA) 95:5 $\rightarrow 5: 95$ $(0 \rightarrow 20 \mathrm{~min})]\left(R_{\mathrm{t}} 15.2 \mathrm{~min}\right)$ absorbance at $222 \mathrm{~nm}$ and $555 \mathrm{~nm}$ and ESI-MS and NMR in $\mathrm{D}_{2} \mathrm{O}$ for Peptide $\mathbf{P}_{8}$. 

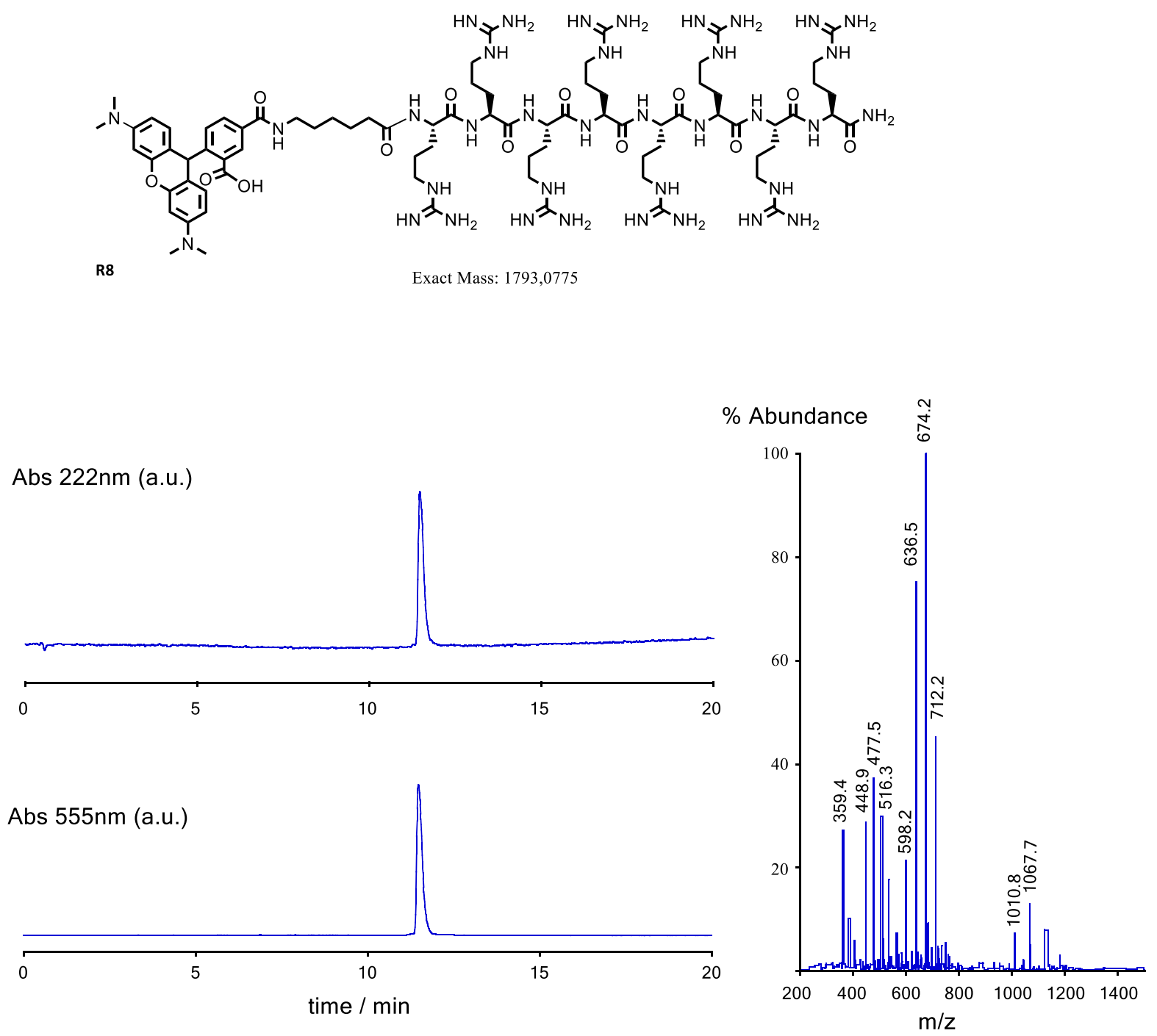

Figure S20: RP-HPLC [Agilent SB-C18 column, $\mathrm{H}_{2} \mathrm{O}(0.1 \%$ TFA $) / \mathrm{CH}_{3} \mathrm{CN}(0.1 \%$ TFA $)$ 95:5 $\rightarrow 5: 95$ $(0 \rightarrow 20 \mathrm{~min})]\left(R_{\mathrm{t}} 11.4 \mathrm{~min}\right)$ absorbance at $222 \mathrm{~nm}$ and $555 \mathrm{~nm}$ and ESI-MS for Peptide $\mathbf{R}_{\mathbf{8}}$. 


\section{Supporting references}

(S1) R. Behrendt, P. White, J. Offer, J. Pept. Sci. 2016, 22, 4-27.

(S2) C. Kay, O. E. Lorthioir, N. J. Parr, M. Congreve, S. C. McKeown, J. J. Scicinski, S. V. Ley, Biotechnol. Bioeng. 2000, 71, 110-118.

(S3) I. Louzao, R. García-Fandiño, J. Montenegro, J. Mater. Chem. B 2017, 5, 4426-4434.

(S4) T. Holm, H. Johansson, P. Lundberg, M. Pooga, M. Lindgren, U. Langel, Nat. Protoc. 2006, 1, $1001-1005$.

(S5) J. P. Richard, K. Melikov, E. Vives, C. Ramos, B. Verbeure, M. J. Gait, L. V Chernomordik, B. Lebleu, J. Biol. Chem. 2003, 278, 585-90. 